\title{
A critical look at challenges and future scopes of bioactive compounds and their incorporations in the food, energy, and pharmaceutical sector
}

\author{
Sanidhya Pai ${ }^{1}$. Akshatha Hebbar ${ }^{2} \cdot$ Subbalaxmi Selvaraj $^{1}$
}

Received: 29 October 2021 / Accepted: 21 February 2022 / Published online: 2 March 2022

(c) The Author(s) 2022

\begin{abstract}
Bioactive compounds refer to secondary metabolites extracted from plants, fungi, microbes, or animals. Besides having pharmacological or toxicological effects on organisms leading to utilization in food and pharmaceutical industries, the discovery of novel properties of such compounds has led to the diversification of their applications, ranging from cosmetics and functionalized biomaterials to bioremediation and alternate fuels. Conventional time-consuming and solvent-intensive methods of extraction are increasingly being replaced by green solvents such as ionic liquids, supercritical fluids, and deep eutectic solvents, as well as non-conventional methods of extraction assisted by microwaves, pulse electric fields, enzymes, ultrasound, or pressure. These methods, along with advances in characterization and optimization strategies, have boosted the commercial viability of extraction especially from agrowastes and organic residues, promoting a sustainable circular economy. Further development of microfluidics, optimization models, nanoencapsulation, and metabolic engineering are expected to overcome certain limitations that restrict the growth of this field, in the context of improving screening, extraction, and economy of processes, as well as retaining biodiversity and enhancing the stability and functionality of such compounds. This review is a compilation of the various extraction and characterization methods employed for bioactive compounds and covers major applications in food, pharmacy, chemicals, energy, and bioremediation. Major limitations and scope of improvement are also discussed.
\end{abstract}

Keywords Bioactive compounds · Extraction · Industrial applications $\cdot$ Pharmaceutical $\cdot$ Characterization

\section{Introduction}

Bioactive compounds engender bioactive properties in the human body without adding any nutritional benefit and fall under secondary metabolites in plants. They express

Responsible Editor: Lotfi Aleya

Sanidhya Pai and Akshatha Hebbar contributed equally to this work as the first authors.

Subbalaxmi Selvaraj

subbalaxmi.s@manipal.edu

1 Department of Biotechnology, Manipal Institute of Technology, Manipal Academy of Higher Education (MAHE), Manipal 576104, India

2 Department of Chemical Engineering, Manipal Institute of Technology, Manipal Academy of Higher Education (MAHE), Manipal 576104, India pharmacological or toxicological effects in humans and other animals (Câmara et al. 2020; Azmir et al. 2013). These compounds are procured from foods such as vegetables, fruits, and whole grains. Natural bioactive compounds are classified as polyphenols, triterpenes and phytosterols, terpenoids, polysaccharides, capsaicinoids, carotenoids and tocopherols, alkaloids, saponins glucosinolates, and others (Makkar et al. 2021). They are also extracted from fungi, animals, and bacteria (Câmara et al. 2020), as well as from agro-industrial residues such as avocado peel, mango seeds, and grape peels (Shirahigue and Antonini 2020).

They manifest antioxidant, anti-allergic, anti-inflammatory, antimicrobial, anticarcinogenic, and antimutagenic properties and are essential for the human body. Moreover, they are also vital in the pharmaceutical, food, and chemical industries (Câmara et al. 2020). Bioactive compounds account for numerous health benefits and help to prevent various diseases and metabolic abnormalities which were proved in several pharmacological studies (Chhikara et al. 
2019). In the food and fermentation industry, bioactive compounds such as essential oils, flavonoids, tannins, phenolic acids, carotenoids, organosulfur compounds, phytosterols, and tocopherols are used in the processing of vegetable oils, meat and seafood products, bakery products, dairy products, etc. (Shirahigue and Antonini 2020). Bioactive compounds are found to have anti-aging properties which are desirable for the cosmetic industry (Câmara et al. 2020).

Diverse types of extraction strategies have been employed over the years, considering properties such as the nature of source matrix, relative solubility, structure, and chemical properties of both the bioactive compound and solvents used, as well as the effect of temperature, pressure, $\mathrm{pH}$, etc. on the time, yield, and selectivity of extraction (Azmir et al. 2013). Conventional methods of extraction include maceration and decoction, which have been widely used in the extraction of essential oils and other bioactive compounds at a household scale (Muala et al. 2021), as well as the model laboratory-scale Soxhlet extraction method that uses slightly elevated temperatures to recirculate solvent within an apparatus and to aid the extraction of compounds from samples placed in a thimble (Raynie 2019).

However, these methods come with limitations, in terms of high extraction times and bulk solvent use, lower efficiencies when relative yields and specificity of extracted compounds are taken into consideration. For example, maceration requires 2 to 7 days for a satisfactory extraction, and the ratios of solvent to crude extract could vary from 4:1 to even around 50:1 in the case of decoction (hot water extraction) (Li et al. 2020). Often, there are requirements of pure and expensive solvents which are toxic. Elevated temperatures used in some methods are unsuitable for the extraction of thermally unstable compounds (Raynie 2019).

Various methods have been developed to overcome the above limitations, in addition to the development of several new types of solvents that are "green," less toxic, cost-effective, and more specific (Pal and Jadeja 2020). Ionic liquids, deep eutectic solvents, and aqueous two-phase systems, for instance, have been incorporated to increase yield and speed of extraction, as well as aid in the extraction of compounds that were too difficult to extract with conventional solvents (Priyadarshi et al. 2020). The solvent-bioactive substance interactions could be compared and optimized using several parameters, such as the Hansen parameters and solvation parameter models (Lefebvre et al 2021).

The basic principle of unconventional extraction methods is assisted extraction using ultrasound, pressurized liquids, microwaves, and pulsed electric fields, with the main aim of cell wall rupture or deterioration, thus enhancing mass transfer and facilitating effective mixing due to the exposure of cytoplasmic contents to the solvent (Lefebvre et al. 2021). Ultrasound-assisted extraction (UAE), pressurized liquid extraction (PLE), microwave-assisted extraction (MAE), supercritical fluid extraction (SCFE), and pulse electric field-assisted extraction (PEFAE) are a few unconventional methods following the above principles. Enzyme-assisted extraction (EAE) has also been considered as an option to extract substances associated with the cell wall, rather than the cytoplasm, by employing enzyme-driven cell wall digestion (Azmir et al. 2013). Supercritical fluid extraction is one of the most popularly used extraction strategies, usually employing supercritical $\mathrm{CO}_{2}$ due to favorable thermodynamic properties and the renewable nature of the solvent (Gan et al. 2020).

The success and efficiency of any method are also determined based on the choice of solvent; the effect of temperature and $\mathrm{pH}$, which could potentially alter cell wall organization, specificity; chemical structure of the compound to be extracted; and feasibility of the process, among other effects. A suitable combination of parameters is arrived at by implementing optimization strategies specific to the process, as shown by Catarino et al. (2019).

Previous reviews have focused on individual aspects of the extraction of bioactive compounds. Sources, applications, and extraction strategies have been documented separately. We aim to provide a comprehensive review explaining bioactive compounds in the food, chemical, and pharmaceutical industry, their sources, extraction methods, and their limitations, characterization, applications, and future scope.

\section{Methods of extraction of bioactive compounds}

The diversity of primary and secondary metabolites of plants and microbes in nature and their innumerable applications in various fields necessitates the use of a vast array of extraction methods, optimized according to their properties (Zhang et al. 2018). Extraction is the process of obtaining a compound of interest from a raw source. It is broadly classified into two types: conventional and non-conventional. Conventional methods include maceration, decoction, and Soxhlet extraction. Most industrial-scale extraction units rely on solvents (notably, hexane), most of which are products of the petrochemical industry. High energy consumption and bulk use of such solvents have adverse environmental impacts (Pal and Jadeja 2020). Non-conventional methods thus focus on using various physical or enzymatic means to enhance extraction (ultrasound, pressure, pulsed electric fields, microwaves, etc.) while utilizing lesser amounts of solvents or specialized "green" solvents (supercritical fluids, deep eutectic mixtures, etc.) (Anticona et al. 2020). Figure 1 represents the classification of extraction methods, along with specific examples under each category. 
Fig. 1 A representation of universally used extraction methods of bioactive compounds

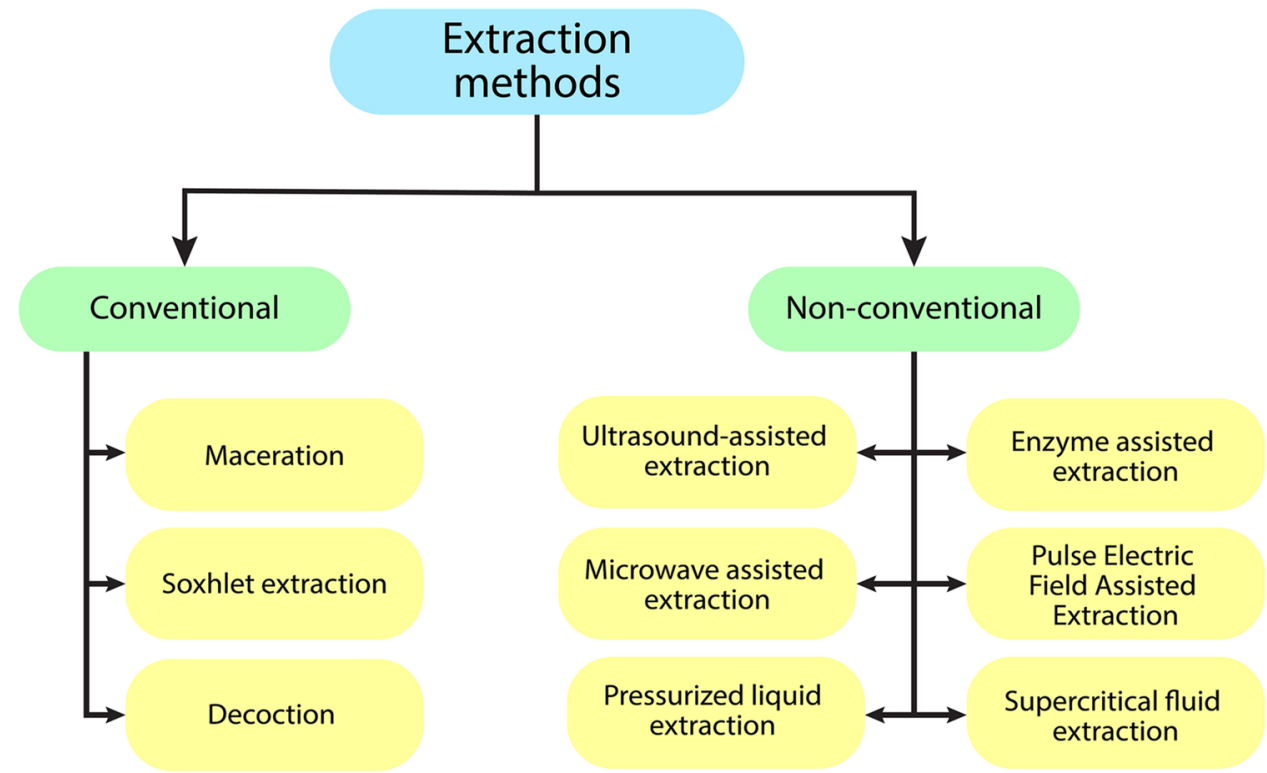

\section{Conventional methods}

\section{Maceration}

Maceration is a table-top extraction method commonly used for the extraction of medicinal plants. Some examples with sources and process conditions are mentioned in Table 1. It involves crushing the raw source coarsely and placing it in a container. The solvent is poured to cover the crushed source completely and is allowed to stand for 3 days with frequent agitation until the soluble matter is dissolved. The mixture is strained and decanted to complete the extraction process (Majekodunmi 2015). Eventually, the extract is separated using evaporation in a water bath. This method is apt for thermolabile plant extracts as it does not require elevated temperatures. However, this extraction process is time-consuming (Zhang et al. 2018).

\section{Soxhlet extraction}

Soxhlet extraction is a model extraction technique, used to extract compounds, traditionally, lipids, from solid or

Table 1 Principle involved, along with various sources, compounds, and process conditions employed in maceration

\begin{tabular}{|c|c|c|c|c|}
\hline Principle & Sources & Compounds extracted & Process conditions & References \\
\hline \multirow[t]{8}{*}{ Heating, infusion } & Chokeberry fruit & Phenols, Anthocyanins & $\begin{array}{l}50 \% \text { ethanol, } 1: 20 \text {, particle } \\
\text { size of } 0.75 \mathrm{~mm}\end{array}$ & Zhang et al. 2018 \\
\hline & $\begin{array}{l}\text { Dried root of } S \text {. baicalensis } \\
\text { Georgi }\end{array}$ & Baicalein & $70 \%$ ethanol & Xie et al. 2019 \\
\hline & Salvia officinalis & Rosmarinic acid, Carnosol & $\begin{array}{l}\text { Boiling water or } 50 \% \text { hydro- } \\
\text { ethanolic solution, } 5 \text { days, } \\
\text { room temperature }\end{array}$ & Vieira et al. 2020 \\
\hline & Piper betle (betel) leaves & Eugenol, Eugenol acetate & $\begin{array}{l}100 \% \text { acetone, } 1: 5,72 \mathrm{~h}, \text { room } \\
\text { temperature }\end{array}$ & Das et al. 2019 \\
\hline & $\begin{array}{l}\text { Anthemis cotula L. (stinking } \\
\text { chamomile) }\end{array}$ & $\begin{array}{l}\text { Anthecotuloid, Caffeoyl quinic } \\
\text { acid and quercetin }\end{array}$ & $\begin{array}{r}96 \% \text { ethanol, } 1: 20, \text { room } \\
\text { temperature, overnight }\end{array}$ & Sut et al. 2019 \\
\hline & Blackcurrant leaves & $\begin{array}{l}\text { Polyphenols (TPC), Flavo- } \\
\text { noids (TFC), and Proantho- } \\
\text { cyanidin oligomers (OPC) }\end{array}$ & $\begin{array}{l}\text { Water, } 1: 100,500 \mathrm{rpm}, 7 \mathrm{~h}, \\
30^{\circ} \mathrm{C}\end{array}$ & Cao-Ngoc et al. 2020 \\
\hline & Red algae Gracilaria gracilis & $\begin{array}{l}\text { Allophycocyanins, Phyco- } \\
\text { erythrins, and Phycocyanins }\end{array}$ & $\begin{array}{l}\text { M phosphate buffer, } \\
10 \text { min; } 1: 50\end{array}$ & Pereira et al. 2020 \\
\hline & $\begin{array}{l}\text { Papery skin of Allium cepa } L . \\
\text { var. ascalonicum (fractions } \\
\text { of Maja Cipanas onion) }\end{array}$ & $\begin{array}{l}\text { Anthocyanin, Alkaloids, } \\
\text { Polyphenols, Tannins, } \\
\text { Flavonoids }\end{array}$ & $\begin{array}{l}70 \% \text { ethanol }+\mathrm{HCl}(2 \mathrm{~N}), 1: 10 \\
\mathrm{pH}: 1,24 \mathrm{~h}, 40^{\circ} \mathrm{C}\end{array}$ & Saptarini and Wardati 2020 \\
\hline
\end{tabular}


semi-solid matrices (Talekar et al. 2018). A porous, usually disposable thimble made of cellulose (Raynie 2019) is placed inside an extraction chamber, to hold the sample. The solvent used for extraction is heated in a round-bottomed flask, which is connected to the extraction chamber. Vapor flows into a condenser, and the condensate is directed to the extraction chamber, where extraction occurs. A siphon redirects the solvent along with the extracted compounds back into the flask below. This process is repeated until extraction is complete (Weggler et al. 2020). Table 2 mentions some of the sources and compounds extracted by Soxhlet extraction as well as the corresponding solvents and process conditions involved. This method is used as a benchmark to compare and develop newer methods. It is also relatively easy to automate, without requiring a lot of supervision (Raynie 2019). However, exceptionally long extraction times (12 to $24 \mathrm{~h}$ ), high energy consumption, and problems in selectivity and efficiency limit the scope of this technique (Weggler et al. 2020; Mussatto 2015; Wianowska and Wiśniewski 2015).

\section{Decoction}

A decoction is a method of extraction of heat-stable bioactive compounds, obtained by boiling in water, which is usually used as a solvent (Hmidani et al. 2019). It is widely used in traditional medicine in the form of oral formulations containing extracts of certain medicinal herbs, due to its capability of a rapid therapeutic action (Wang et al. 2019). Common sources include hard8 solids such as roots, bark, and seeds, which are ground and heated with water in a closed vessel. The extract is then cooled and filtered from the insoluble residue (Perera et al. 2017). Table 3 gives a general overview of the various compounds extracted by decoction, along with corresponding sources and process conditions. A decoction is characterized by noticeably short extraction times of around 5 to $10 \mathrm{~min}$. However, this might be a disadvantage if the bioactive compounds that must be extracted are not so soluble in water. In addition to this, there is a large solvent to solid ratio involved (Zhang et al. 2018).

Table 2 Principle involved, along with various sources, compounds extracted, solvents used, and the corresponding process conditions used in Soxhlet extraction

\begin{tabular}{|c|c|c|c|c|}
\hline Principle & Sources & Compounds extracted & Process conditions & References \\
\hline \multirow[t]{10}{*}{$\begin{array}{l}\text { Heating, condensation, } \\
\text { extraction, and reflux } \\
\text { of S within a Soxhlet } \\
\text { apparatus }\end{array}$} & \multirow[t]{2}{*}{ Spent coffee (silverskin) } & Caffeine & $\begin{array}{l}\text { Hexane, dichlorometh- } \\
\text { ane, ethanol, } 1: 50,6 \mathrm{~h}, \\
\text { the temperature was a } \\
\text { solvent boiling point }\end{array}$ & \multirow[t]{2}{*}{ Mussatto et al., 2015} \\
\hline & & Chlorogenic acid & $\begin{array}{l}60 \% \text { isopropanol }(60 \%), \\
1: 10 \\
27{ }^{\circ} \mathrm{C}\end{array}$ & \\
\hline & $\begin{array}{l}\text { Waste Punica granatum } L . \\
\text { (pomegranate) seeds }\end{array}$ & Oils (PUFAs, punicic acid) & Hexane, $1: 15,4 \mathrm{~h}, 60^{\circ} \mathrm{C}$ & Talekar et al., 2018 \\
\hline & $\begin{array}{l}\text { Rosmarinus officinalis } L \text {. } \\
\text { (rosemary) leaves }\end{array}$ & $\begin{array}{l}\text { Rosmarinic acid, Carnosic } \\
\text { acid, Carnosol }\end{array}$ & $\begin{array}{l}96 \% \text { food grade ethanol, } \\
\text { demineralized water, } \\
1: 12, \\
8 \mathrm{~h}\end{array}$ & Hirondart et al. 2020 \\
\hline & Piper betle (betel) leaves & Eugenol, Eugenol acetate & $\begin{array}{l}100 \% \text { acetone, } 1: 5,56^{\circ} \mathrm{C} \text {, } \\
8 \mathrm{~h}\end{array}$ & Das et al., 2019 \\
\hline & Agaricus bisporus $L$ & Ergosterol & $\begin{array}{l}\text { Hexane, ethanol, or } \\
\text { limonene ( } 150 \mathrm{~mL} \text { for } \\
4.5 \mathrm{~g} \text { of sample), } 4 \mathrm{~h} \text {, }\end{array}$ & Heleno et al., 2016 \\
\hline & $\begin{array}{l}\text { Anthemis cotula L. (stink- } \\
\text { ing chamomile) }\end{array}$ & $\begin{array}{l}\text { Anthecotuloid, Caffeoyl } \\
\text { Quinic acid, and Querce- } \\
\text { tin }\end{array}$ & $96 \%$ ethanol, $1: 20,6 \mathrm{~h}$ & Sut et al, 2019 \\
\hline & $\begin{array}{l}\text { Allium cepa } L . \text { var. } \\
\text { ascalonicum }\end{array}$ & $\begin{array}{l}\text { Alkaloids, Polyphenols, } \\
\text { Tannins, Flavonoids }\end{array}$ & $\begin{array}{l}70 \% \text { ethanol }+\mathrm{HCl} \\
(2 \mathrm{~N}), 1: 10 \\
\mathrm{pH}: 1,2 \mathrm{~h}\end{array}$ & Saptarini and Wardati, 2020 \\
\hline & $\begin{array}{l}\text { Silybum marianum } L . \\
\text { Gaertner fruits }\end{array}$ & Silymarin & $\begin{array}{l}\text { n-hexane (defatting), } \\
\text { methanol (for Silymarin } \\
\text { extraction), } 2: 75,6 \mathrm{~h} \\
\text { (defatting) }+5 \mathrm{~h} \text { (actual } \\
\text { extraction) }\end{array}$ & $\begin{array}{l}\text { Wianowska and Wiśniewski, } \\
2015\end{array}$ \\
\hline & $\begin{array}{l}\text { Miscanthus sinensis (runo) } \\
\text { stem }\end{array}$ & Runo dye & $50 \%$ ethanol and $4 \mathrm{~h}$ & Pinzon et al., 2020 \\
\hline
\end{tabular}


Table 3 Principle involved, along with the various sources, compounds extracted, and the corresponding process conditions used in decoction

\begin{tabular}{|c|c|c|c|c|}
\hline Principle & Sources & Compounds extracted & Process conditions & References \\
\hline \multirow[t]{9}{*}{$\begin{array}{l}\text { Heating or boiling solids } \\
\text { in an aqueous medium }\end{array}$} & Syzygium cumini bark & $\begin{array}{l}\text { Gallic acid, Umbelliferone, } \\
\text { Ellagic acid }\end{array}$ & $\begin{array}{l}\text { Water, } 16 \mathrm{~mL} / \mathrm{g} \text { of powdered } \\
\text { bark }\end{array}$ & Perera et al., 2017 \\
\hline & Astragalus membranaceus & Astragaloside IV & Water & Zhang et al., 2020a, b \\
\hline & $\begin{array}{l}\text { Berry (Strawberry, rasp- } \\
\text { berry, blueberry, black- } \\
\text { berry) }\end{array}$ & $\begin{array}{l}\text { Anthocyanins, Hydroxycin- } \\
\text { namic acids (extractable } \\
\text { fraction); Ellagic acid, } \\
\text { Hydroxybenzoic acid } \\
\text { (hydrolyzable fraction) }\end{array}$ & Water & $\begin{array}{l}\text { Reynoso-Camacho et al., } \\
2021\end{array}$ \\
\hline & $\begin{array}{l}\text { Santolina impressa (leaves, } \\
\text { inflorescence) }\end{array}$ & Chlorogenic acid, Cynarin & $\begin{array}{l}\text { Distilled water, } 10 \mathrm{~mL} / \mathrm{g} \text {, } \\
10 \mathrm{~min} \text {, and } 100{ }^{\circ} \mathrm{C}\end{array}$ & Rodrigues et al., 2020 \\
\hline & $\begin{array}{l}\text { Actinidia deliciosa (kiwi- } \\
\text { fruit) }\end{array}$ & $\begin{array}{l}\text { Quinic acid, Caffeic acid, } \\
\text { Caffeoyl hexoside }\end{array}$ & $\begin{array}{l}\text { Distilled water, } 50 \mathrm{~mL} / \mathrm{g} \text {, } \\
5 \mathrm{~min} \text { at } 100^{\circ} \mathrm{C}\end{array}$ & Silva et al., 2019 \\
\hline & A. arguta (kiwiberry) & $\begin{array}{l}\text { Quinic acid, Cis-caftaric } \\
\text { acid, Myristin, Caffeoyl } \\
\text { hexoside, Luteolin glucu- } \\
\text { ronide, etc }\end{array}$ & & \\
\hline & $\begin{array}{l}\text { Cymbopogon citratus (lem- } \\
\text { ongrass) leaves }\end{array}$ & $\begin{array}{l}\text { Caffeic acid, Syringic acid, } \\
\text { Citral, Geraniol }\end{array}$ & $\begin{array}{l}\text { Distilled water, } 93.8^{\circ} \mathrm{C} \text {, } \\
11.3 \text { min, and } 1: 5\end{array}$ & Muala et al., 2021 \\
\hline & $\begin{array}{l}\text { Thymus atlanticus (Moroc- } \\
\text { can thyme) }\end{array}$ & $\begin{array}{l}\text { Polyphenols, flavonoids (ros- } \\
\text { marinic acid, caffeic acid) }\end{array}$ & $\begin{array}{l}\text { Bidistilled water, } 25 \mathrm{~mL} / \mathrm{g} \text {, } \\
100{ }^{\circ} \mathrm{C} \text {, and } 30 \mathrm{~min}\end{array}$ & Hmidani et al., 2019 \\
\hline & Uncaria rhynchophylla & Uncarophyllofolic acids & $\begin{array}{l}\text { Water, 9.2 } \mathrm{mL} / \mathrm{g} \text {, and } \\
30 \mathrm{~min}\end{array}$ & Wang et al., 2019 \\
\hline
\end{tabular}

\section{Advanced methods of extraction}

\section{Ultrasound-assisted extraction (UAE)}

UAE is performed on both laboratory scale and industrial scale. It is carried out using ultrasonic waves to cause cavitation which leads to the implosion of bubbles in the medium. Cavitation induces collisions, macroturbulence, and disruption of the solid particles. It creates pores and enlarges them which in turn increase the mass transfer rate and the penetration of solvents into the biomass (Gonzalez et al. 2020). UAE can be set up in different configurations depending on the requirements of the extraction process. The transducer is directly dipped in the bulk. It makes the process effective but increases the chances of contamination (Esclapez et al. 2011). Consecutively, different methods of extraction are used to determine the quantity of the desired contents. UAE can be performed with a variety of solvents such as water, ethanol, methanol, acetone, and ethyl acetate, but it must be carried out at a lower temperature to maintain the integrity of thermosensitive compounds (Roohinejad et al. 2017). A few compounds that are extracted using UAE along with sources, solvents, and process conditions are listed in Table 4.

\section{Microwave-assisted extraction (MAE)}

This is a technique that assists extraction by irradiating microwaves (frequency range: $300 \mathrm{MHz}$ to $300 \mathrm{GHz}$ ) onto the sample (Rehman et al. 2020). Energy associated with these microwaves is converted to thermal energy as the moisture present within the cells starts to evaporate due to ionic conduction as well as dipole rotation, two phenomena associated with microwave technology (Zghaibi et al. 2019). As a result, the cells experience a pressure build-up, eventually causing them to rupture, thus releasing the bioactive compounds (Pinzon et al. 2020). This technique has gained a lot of interest due to its ability to use extraordinarily little quantities of solvents and rapid extraction times, as well as greater reproducibility and control of process conditions such as temperature and pressure (Milani et al. 2020). The principles involved in this technique also facilitate a homogeneous temperature distribution, which also aids in higher yields and favorable heat and mass transfer from the sample to solvent (Pinzon et al. 2020). Table 5 provides an overview of the sources and various compounds extracted using this technique, along with the necessary parameters required for optimal yields.

\section{Pressurized liquid extraction (PLE)}

PLE involves the use of solvents at elevated temperatures, lower than their respective critical points to maintain them in the liquid state. This process exploits the mass transfer properties at elevated temperatures and pressures (Zakaria et al. 2020). The process involves moistening the sample with the solvent. The desired compound desorbs from the sample and gets absorbed in the extraction solvent. 
Table 4 Principle, sources, compounds, and process conditions employed in ultrasound-assisted extraction

\begin{tabular}{|c|c|c|c|c|}
\hline Principle & Sources & Compounds extracted & Process conditions & References \\
\hline \multirow{11}{*}{$\begin{array}{l}\text { Cavitation induces colli- } \\
\text { sions and shear in the } \\
\text { reaction mixture which } \\
\text { leads to disruption of solid } \\
\text { particles }\end{array}$} & Banana bract & Dietary fiber & $\mathrm{NaOH}, 20 \mathrm{kHz}, 10 \mathrm{~min}$ & Kumar et al., 2021 \\
\hline & Grape seed & Malic acid and Tartaric acid & $\begin{array}{l}\text { Water and methanol, } \\
24 \mathrm{kHz}, 5 \text { and } 10 \mathrm{~min}\end{array}$ & \\
\hline & Bitter gourd & $\begin{array}{l}\text { Total polyphenols or GAE } \\
\text { (gallic acid equivalents) }\end{array}$ & $\begin{array}{l}\text { Water, } 68.4^{\circ} \mathrm{C}, 11.6 \mathrm{~min} \text {, } \\
\text { vegetable to water ratio: } \\
0.3 \mathrm{~g} / \mathrm{L}\end{array}$ & Chakraborty et al. 2020 \\
\hline & Tannat grape pomace & $\begin{array}{l}\text { Polyphenols and Total } \\
\text { anthocyanins }\end{array}$ & Ethanol, $1: 20,30^{\circ} \mathrm{C}$ & González et al. 2020 \\
\hline & $\begin{array}{l}\text { Saffron (Crocus sativus) } \\
\text { petals }\end{array}$ & $\begin{array}{l}\text { Crocin,Ssafranal, Catechin, } \\
\text { and Epicatechin }\end{array}$ & $\begin{array}{l}\text { Distilled water and } \mathrm{NaCl} \text {, } \\
40.61 \text { min, power: }\end{array}$ & Hashemi et al. 2020 \\
\hline & & $\begin{array}{l}\text { Delphinidin 3,5-di-O- } \\
\text { glucoside }\end{array}$ & $\begin{array}{l}135.3 \mathrm{~W}, 5 \mathrm{~g} \text { of dried } \\
\text { petals }\end{array}$ & \\
\hline & & Quercitin 3-O-glucoside, & $\begin{array}{l}\text { added into } 100 \mathrm{~mL} \text { of } \\
\text { distilled water containing } \\
0.3 \mathrm{~g} \mathrm{NaCl}\end{array}$ & \\
\hline & $\begin{array}{l}\text { Stevia rebaudiana Bertoni } \\
\text { leaves }\end{array}$ & $\begin{array}{l}\text { Steviol glycosides, Phenolic } \\
\text { compounds }\end{array}$ & Water, $100^{\circ} \mathrm{C}, 24 \mathrm{~h}$ & Žlabur et al., 2015 \\
\hline & Agaricus bisporus $L$ & Ergosterol, Gallic acid & Ethanol, $15 \mathrm{~min}, 375 \mathrm{~W}$ & Heleno et al., 2016 \\
\hline & $\begin{array}{l}\text { Anthemis cotula L. (stinking } \\
\text { chamomile) }\end{array}$ & $\begin{array}{l}\text { Anthecotuloid, Caffeoyl } \\
\text { quinic acid and Quercetin }\end{array}$ & $\begin{array}{l}96 \% \text { ethanol, } 1: 20,60 \mathrm{~min} \text {, } \\
30^{\circ} \mathrm{C}\end{array}$ & Sut et al. 2019 \\
\hline & Morinda citrifolia $L$. fruits & Noni polysaccharides & $\begin{array}{l}\text { Distilled Water, } 1: 33,78^{\circ} \mathrm{C} \text {, } \\
81.7 \mathrm{~min}\end{array}$ & Li et al. 2020 \\
\hline
\end{tabular}

The temperature being the key parameter of PLE is used to modify the physicochemical properties of the solvent (Anticona et al. 2020). There are two types of setups used for PLE: static and dynamic, as well as a combination of both. The dynamic system includes a continuous pumping of aliquots of the solvent, the rate being around $0.5-2.5 \mathrm{ml} /$ min. In the static method, the extracted solvent is collected every 5-10 min (Vazquez-Roig and Picó 2015). PLE is used in the contamination analysis in complex matrices such as food. It can be used to identify tenacious organic pollutants (Ridgway 2012). Table 6 lists out a few compounds that are extracted using PLE as well as the sources, required solvents, and process conditions.

\section{Enzyme-assisted extraction (EAE)}

Enzyme-assisted extraction is useful when it comes to the extraction of phytochemicals associated with the cell wall. The presence of cellulose, hemicellulose, and lignin in higher concentrations makes it difficult to implement other popular extraction techniques (Nadar et al. 2018). EAE overcomes this problem by employing enzymes such as cellulase, pectinase, and alpha-amylase involved in the digestion of the cell wall (Azmir et al. 2013). This method has several advantages in terms of environmentally friendly methods and lower consumption of energy and equipment compared to other techniques, reduced usage of toxic solvents, and efficient extraction of thermally sensitive and volatile compounds used as fragrances, flavors, pigments, etc. (Nadar et al. 2018). This method has immense potential and several bioactive compounds of industrial and pharmaceutical importance have been successfully extracted (Table 7) However, enzymes are too expensive to be utilized for extraction of large volumes of substances. Designing efficient ways to scale up such processes is also a challenge (Franco et al. 2020).

\section{Pulse electric field-assisted extraction (PEFAE)}

This extraction technique works on the principle of electroporation. This occurs when cells are exposed to high-intensity electric field pulses that charge cell membranes, eventually creating pores due to increased repulsive forces between membrane constituents, usually after the transmembrane potential crosses a value of $1 \mathrm{~V}$ (Gorte et al. 2020). Static bench-scale equipment usually consists of a high voltage power generator, a digital oscilloscope (to monitor voltage, current, frequency, etc.) and a treatment chamber, where the sample is placed (Bozinou et al. 2019). This method is an alternative to other 
Table 5 Various bioactive compounds extracted by microwave-assisted extraction, along with the principle, respective sources, and process parameters

\begin{tabular}{|c|c|c|c|c|}
\hline Principle & Sources & Compounds extracted & Process conditions & References \\
\hline \multirow{9}{*}{$\begin{array}{l}\text { Microwave irradiation, } \\
\text { intracellular moisture } \\
\text { evaporation, pressure } \\
\text { build-up, and rupture of } \\
\text { cells }\end{array}$} & $\begin{array}{l}\text { Anthemis cotula L. (stink- } \\
\text { ing chamomile) }\end{array}$ & $\begin{array}{l}\text { Anthecotuloid, } \\
\text { Caffeoylquinic acid, and } \\
\text { Quercetin }\end{array}$ & $\begin{array}{l}96 \% \text { ethanol, } 1: 20 \text {, } \\
30 \mathrm{~min}, 600 \mathrm{~W}\end{array}$ & Sut et al. 2019 \\
\hline & $\begin{array}{l}\text { Miscanthus sinensis (runo) } \\
\text { stem }\end{array}$ & Runo dye & $50 \%$ ethanol, $15 \mathrm{~s}, 540 \mathrm{~W}$ & Pinzon et al. 2020 \\
\hline & $\begin{array}{l}\text { Phyllostachys pubescens } \\
\text { (bamboo) }\end{array}$ & Polyphenols, Favonoids & $\begin{array}{l}\text { Methanol, } 6.25 \mathrm{~g} / \mathrm{mL} \text {, } \\
105^{\circ} \mathrm{C} \text {, and } 4 \mathrm{~min}\end{array}$ & Milani et al. 2020 \\
\hline & $\begin{array}{l}\text { Nannochloropsis sp. } \\
\text { (microalgae) }\end{array}$ & $\begin{array}{l}\text { Lipids (PUFAs and } \\
\text { omega-3 fatty acids) }\end{array}$ & $\begin{array}{l}10 \% \text { brine } 1: 20 \text {, } \\
100{ }^{\circ} \mathrm{C} \text {, and } 30 \mathrm{~min}\end{array}$ & Zghaibi et al. 2019 \\
\hline & Hemp nut & $\begin{array}{l}\text { Cannabinoids (cannabidiol, } \\
\text { cannabinol, tetrahydro- } \\
\text { cannabinol) }\end{array}$ & $\begin{array}{l}\text { Methanol, } 375 \mathrm{~W} \text {, } \\
109^{\circ} \mathrm{C} \text {, and } 30 \mathrm{~min}\end{array}$ & Chang et al. 2017 \\
\hline & A. nodosum & $\begin{array}{l}\text { Fucose sulfated polysac- } \\
\text { charides }\end{array}$ & $1000 \mathrm{~W}$, and $5 \mathrm{~min}$ & Garcia-Vaquero et al. 2020 \\
\hline & Fucus vesiculosus & $\begin{array}{l}\text { Fucose sulfated polysac- } \\
\text { charides }\end{array}$ & $\begin{array}{l}\text { Water, } 120 \mathrm{psi}, 1 \mathrm{~min} \text {, and } \\
1: 25\end{array}$ & Rodriguez-Jasso et al. 2011 \\
\hline & $\begin{array}{l}\text { Mangifera indica } L \text {. } \\
\quad(\text { mango) peel }\end{array}$ & Mangiferin & $\begin{array}{l}\text { Deep eutectic mixture } \\
\text { of lactic acid, sodium } \\
\text { acetate, and water } \\
(3: 1: 4), 436.45 \mathrm{~W}, \\
19.6 \mathrm{~min} \text {, and } 59.8 \mathrm{~mL} / \mathrm{g}\end{array}$ & Pal and Jadeja 2020 \\
\hline & Coriander & Heneicos-1-ene & $\begin{array}{l}\text { Ionic solvents (BMIM- } \\
\text { BF4) }(0.1 \mathrm{M}), 800 \mathrm{~W} \text {, } \\
90{ }^{\circ} \mathrm{C}, 2 \mathrm{~min}, 1: 10\end{array}$ & Priyadarshi et al. 2020 \\
\hline
\end{tabular}

Table 6 Principle, sources, compounds, and process conditions used in pressurized liquid extraction

\begin{tabular}{|c|c|c|c|c|}
\hline Principle & Sources & Compounds extracted & Process conditions & Reference \\
\hline \multirow{9}{*}{$\begin{array}{l}\text { Extract targeted analytes } \\
\text { from a sample matrix } \\
\text { into a small amount of S } \\
\text { using high Ts and pres- } \\
\text { sures }\end{array}$} & $\begin{array}{l}\text { Rosmarinus officinalis } L . \\
\quad \text { (rosemary) leaves }\end{array}$ & $\begin{array}{l}\text { Rosmarinic acid, Carnosic } \\
\text { acid, Carnosol }\end{array}$ & $\begin{array}{l}183^{\circ} \mathrm{C}, 130 \mathrm{bar} \text {, and } \\
3 \mathrm{~min}\end{array}$ & Hirondart et al. 2020 \\
\hline & $\begin{array}{l}\text { Silybum marianum } L . \\
\text { Gaertner fruits }\end{array}$ & Silymarin & $\begin{array}{l}\text { Acetone, } 125^{\circ} \mathrm{C}, 10 \mathrm{~min} \text {, } \\
\text { and } 60 \mathrm{bar}\end{array}$ & $\begin{array}{l}\text { Wianowska and Wiśniewski } \\
2015\end{array}$ \\
\hline & Feijoa leaf & $\begin{array}{l}\text { Gallic acid, Catechin and } \\
\text { Isoquercetin }\end{array}$ & Ethanol-water, $80^{\circ} \mathrm{C}$ & Santos et al. 2021 \\
\hline & Orange peel & $\begin{array}{l}\text { Hesperidin, Naringin, } \\
\text { Narirutin, tangeretin, } \\
\text { naringenin, hesperidin }\end{array}$ & $\begin{array}{l}75 \% \text { ethanol, } 65^{\circ} \mathrm{C} \\
40 \mathrm{~min} \text {, and } 10 \mathrm{MPa}\end{array}$ & Anticona et al. 2020 \\
\hline & underutilized chia seeds & $\begin{array}{l}\text { Omega 3-rich oils (ALA } \\
\text { and Linoleic acid) }\end{array}$ & $\begin{array}{l}\text { Ethanol, } 60^{\circ} \mathrm{C} \text {, and } \\
10 \mathrm{~min}\end{array}$ & Villanueva-Bermejo, 2019 \\
\hline & Moringa oleifera leaves & Phenolic compounds & $\begin{array}{l}35 \% \text { ethanol, } 128{ }^{\circ} \mathrm{C}, \\
20 \text { min }\end{array}$ & Rodríguez-Pérez et al. 2016 \\
\hline & Neochloris oleoabundans & Carotenoids & $\begin{array}{l}\text { Ethanol, } 100{ }^{\circ} \mathrm{C}, \\
20 \mathrm{~min}, 1500 \mathrm{psi}, 0.6 \mathrm{~g} \\
\text { algae }+2 \mathrm{~g} \text { sea-sand }\end{array}$ & Castro-Puyana et al. 2017 \\
\hline & Fucus vesiculosus & $\begin{array}{l}\text { Gallic, Protocatechuic, and } \\
\text { Gentisic acids }\end{array}$ & $\begin{array}{l}58.65 \% \text { ethanol, } \\
137.18{ }^{\circ} \mathrm{C}, \\
\text { and } 4.68 \mathrm{~min},\end{array}$ & Sumampouw et al. 2021 \\
\hline & Chlorella sp. microalgae & Phenolic compounds & $\begin{array}{l}\text { Water, } 100{ }^{\circ} \mathrm{C} \text { and } 250^{\circ} \mathrm{C} \text {, } \\
\text { and } 5 \text { to } 20 \mathrm{~min}\end{array}$ & Zakaria et al. 2020 \\
\hline
\end{tabular}




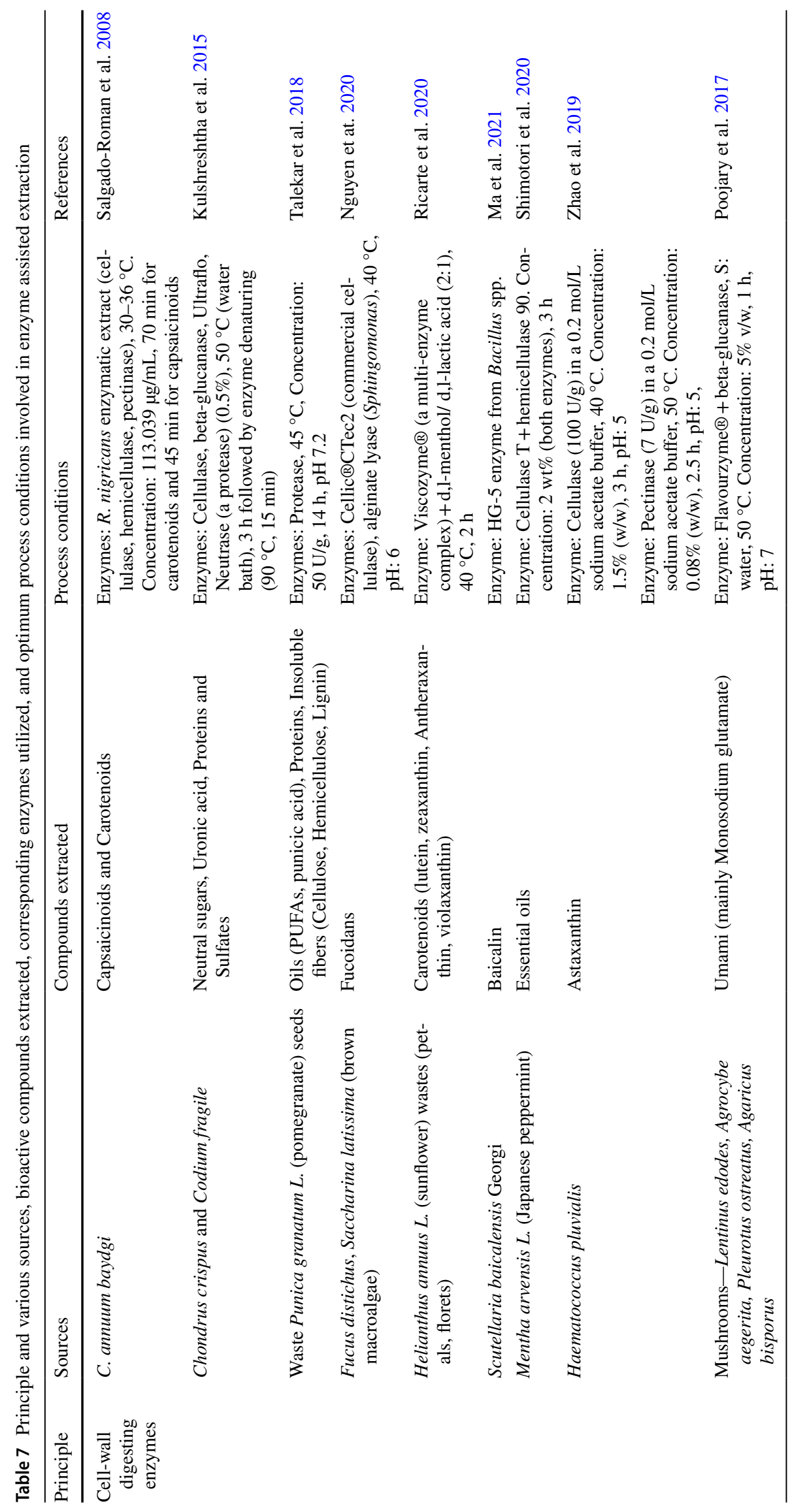


techniques because it increases permeability (and hence, extraction rates) without creating cellular debris, thus increasing the purity of the product (Martínez et al. 2020). In addition to its scalability and selectivity, this method is convenient for the extraction of compounds from wet biomass since it eliminates the need for drying (Carullo et al. 2020). Various compounds that have been previously extracted with this method, along with solvents, sources, and other process parameters, have been listed in Table 8 . PEFAE allows exposure of electric pulses without a drastic temperature increase, which prevents the disintegration of thermally unstable compounds (Kokkali et al. 2020). However, process parameters such as field strength and pulse number specifically depend on the composition of the medium and its tendency to generate a potential in response to electric field pulses. High equipment costs limit extensive use of this technology.

\section{Supercritical fluid extraction (SFE)}

SFE is a highly specific extraction method used in pharmaceutical, chemical, and food industries, to extract surfactants, food additives, and fragrant compounds, with $\mathrm{CO}_{2}$ as the main solvent. Thermosensitive bioactive compounds face minimal damage because of the low critical temperature of $\mathrm{CO}_{2}$ (Uwineza and Waśkiewicz 2020). Table 9 lists out a few compounds extracted with SFE along with the sources, solvents, and process conditions. SFE operates in supercritical solvent conditions at elevated temperatures and pressures which makes the process more efficient as it enables the gas-like solvent to penetrate the solid matrices. The key conditions: temperature and pressure of the supercritical fluid can significantly alter the selectivity as well as solubility (Villanueva-Bermejo et al. 2019). Supercritical $\mathrm{CO}_{2}$ is the most common solvent used for SFE as it exists as a gas at room temperature and can be separated from the extraction mixture easily. Furthermore, it has moderate critical temperature and pressure (Al Jitan et al. 2018). However, the low polarity of $\mathrm{CO}_{2}$ makes it undesirable to extract polar compounds. To overcome this challenge, $\mathrm{NO}_{2}$ is used as an alternative to extract polar compounds (Capuzzo et al. 2013). An SFE setup involves a condenser, an extractor, and separators. The $\mathrm{CO}_{2}$ from the condenser is pressurized and passed into the system whilst the temperature is being regulated. The extractor is depressurized, and the cylinder containing the raw material is fed into the extractor. The system is pressurized, and the $\mathrm{scCO}_{2}$ is allowed to enter the extractor in a regulated flow till the extraction process is complete. The $\mathrm{scCO}_{2}$ is recirculated to the condenser, and the extracts will be collected in the separators (Baysal et al. 2000). Costly setup is the major disadvantage of SFE (Uwineza and Waśkiewicz 2020).

\section{Characterization of bioactive compounds}

A plethora of bioactive compounds exist in multi-component states which make the isolation and separation and characterization process a crucial task. Characterization is a process that is performed to obtain a pure form of the target bioactive compound which helps in determining the amount, structure, and biological activity of the compound (Mahato et al. 2019). It plays a key role in the identification of potentially bioactive compounds with novel functionalities, including but not limited to drugs and antimicrobials. This is important in areas where these substances were traditionally used, but their exact chemical structure and properties were left undocumented (Ayalew 2020). Various chromatographic techniques have been developed to fractionate various kinds of compounds present in a single extract, such as ion exchange chromatography (IEC), thin layer chromatography (TLC), size exclusion chromatography (SEC), high-speed counter current chromatography (HSCCC), and high-performance thin layer chromatography (HPTLC). More advanced methods such as nuclear magnetic resonance (NMR), mass spectrometry (MS), Fourier transform infrared spectroscopy (FTIR), and so on are more selective and enable an analysis of bioactive compounds at molecular levels (García-Vaquero and Rajauria 2018). Table 10 describes various methods of characterization that are employed, in addition to the principles involved and compounds that have been identified by each method.

\section{Applications of bioactive compounds}

In this study, the applications of bioactive compounds in five major sectors such as food, pharmaceutical, bioremediation, energy, and chemical along with their major sources and important compounds extracted were discussed (Fig. 2).

\section{Food sector}

Bioactive compounds add a substantial value to the food industry. Food and nutrient supplements (Talekar et al. 2018), food coloring (Chhikara et al. 2019), meat and meat products (Pogorzelska-Nowicka et al. 2018), etc. all contain bioactive compounds necessary for the human body as mentioned before. They are added as a food enhancer as well, for example, carotenoids, curcumin, and anthocyanins are used as coloring agents; ascorbic acid is used widely as an additive to prevent oxidation in foods; vanillin and cinnamaldehyde are used as flavoring agents. Fermentation is one of the main areas under the food industry that produces a lot of bioactive compounds (Sadh et al. 2018) 


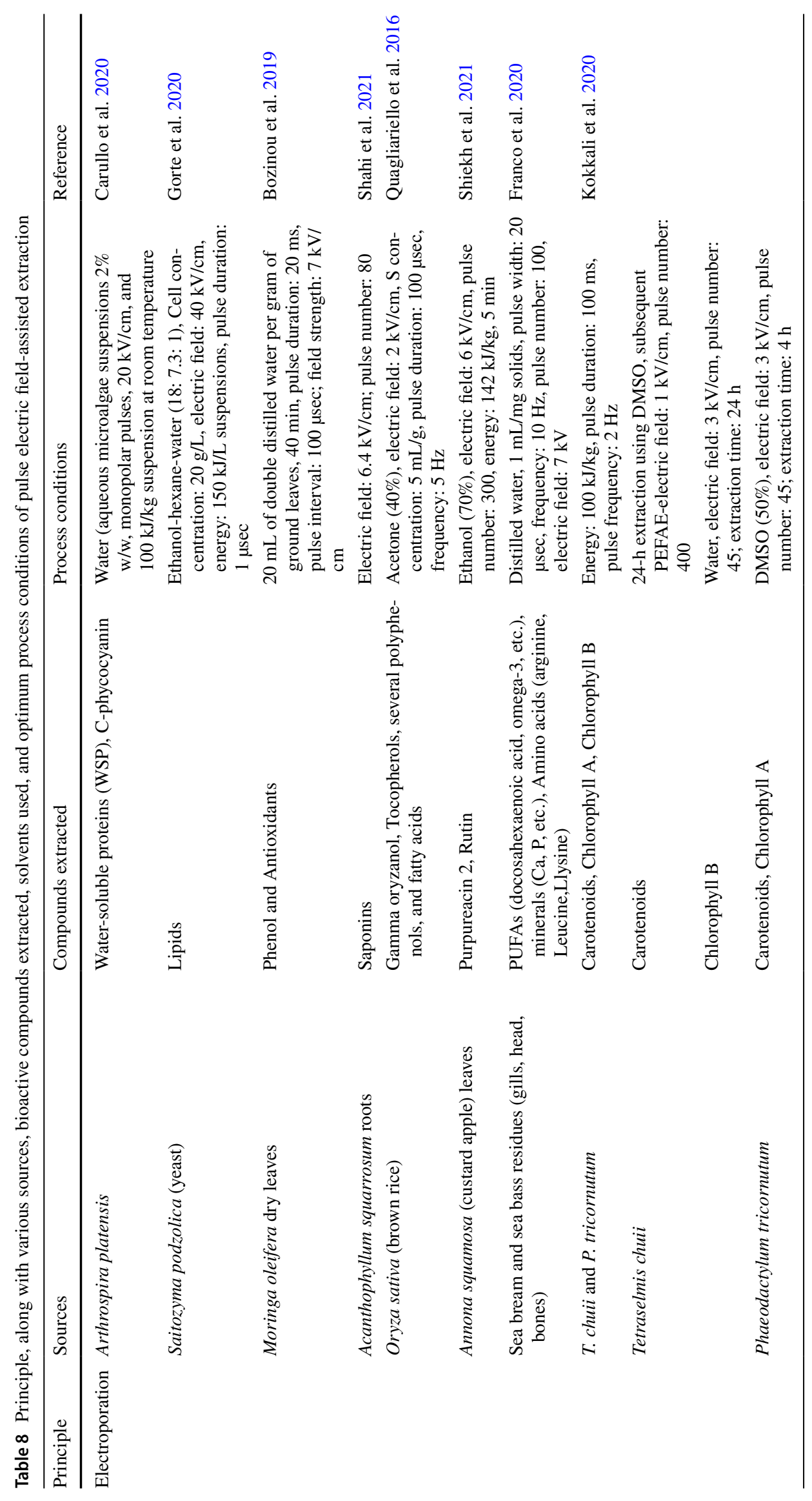


Fig. 2 Five major applications of bioactive compounds, along with a few sources as well as important compounds

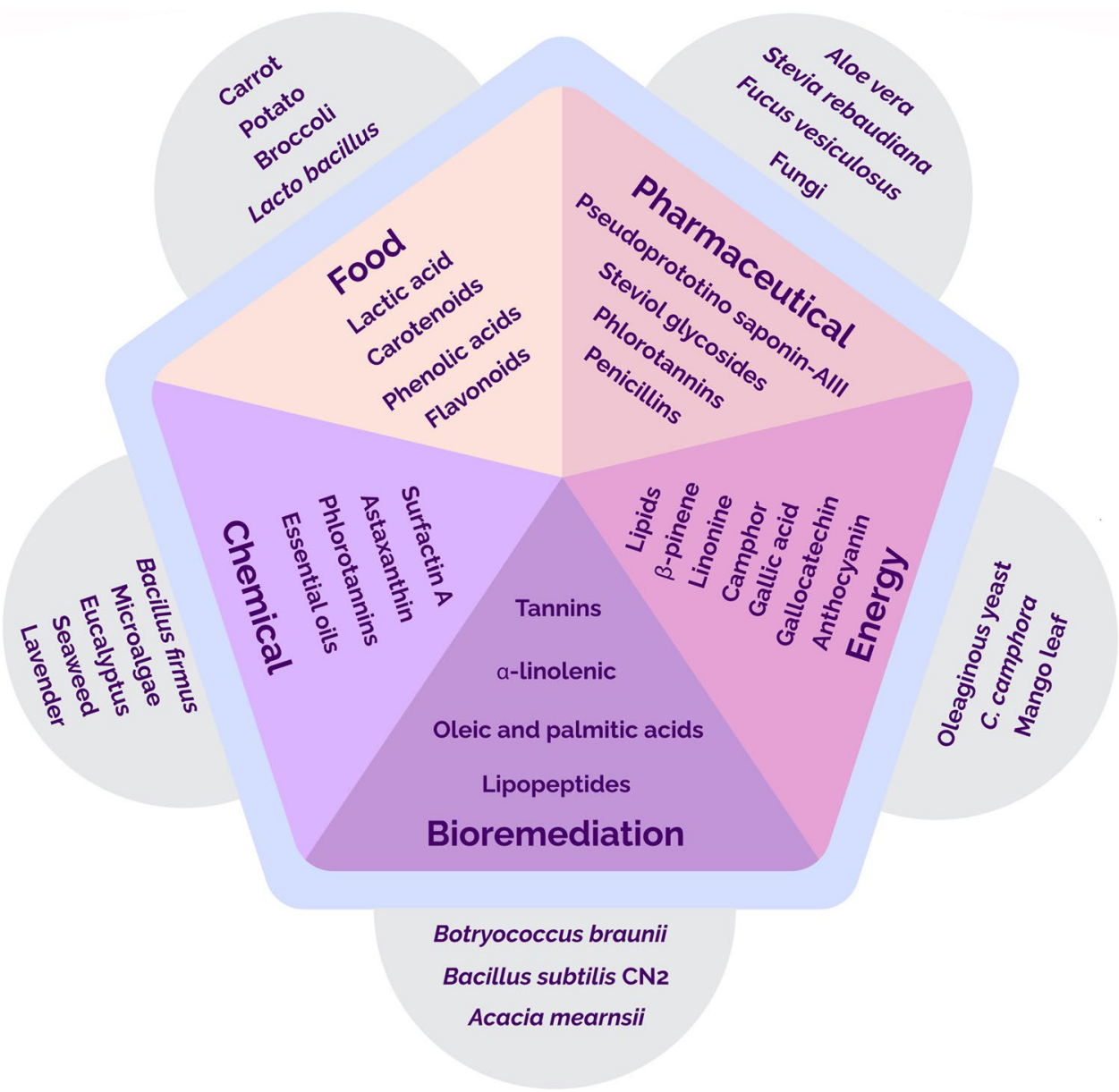

such as single-cell proteins used as an alternative source for protein (Ritala et al. 2017); lactic acid used for acidulation and preservation (Miller et al. 2011); xanthan used as an emulsifier, thickener, and stabilizer (Habibi and KhosraviDarani 2017); laccase used for baking and in the beverage industry as a stabilizer (Mayolo-Deloisa et al. 2020); astaxanthin used as a coloring agent (Gwaltney-Brant 2021); citric acid used as a food preservative and flavoring agent (Kazmi and Clark 2012); fumaric acid used as an acidulant (Karaffa and Kubicek 2021); and others. The main sources of such bioactive compounds are fruits, wastes produced in the wine industry, plant, fruit, and vegetable waste like peels, seeds, and pomace (Shirahigue and Antonini 2020). Common fruits such as apple, mango, plum, banana, and citrus fruits contain phenolic acids, flavanols, carotenoids, anthocyanins, and lipids. Common vegetables like potato, carrot, beetroot, and broccoli contain carbohydrates, phenolic acids, carotenoids, and flavonoids. A few other sources of carotenoids are Neochloris oleoabundans, C. annuum baydgi, Helianthus annuus L. (sunflower) wastes (petals, florets), T. chuii, and P. tricornutum. Chokeberry fruit, papery skin of Allium cepa L. var. Ascalonicum, strawberry, raspberry, blueberry, blackberry, and Tannat grape pomace are a few sources of anthocyanins. Phenols and polyphenols are extracted from Thymus atlanticus (Moroccan thyme), bitter gourd, Tannat grape pomace, Phyllostachys pubescens (bamboo), and Oryza sativa (brown rice) to name a few sources. The sources mentioned above are listed in the extraction tables (Tables 1-9).

\section{Pharmaceutical and therapeutic sector}

The development of completely novel compounds for therapeutics is a daunting and time-consuming task (Sinha and Häder 2021). This has helped steer major advances in the utilization of a vast diversity of bioactive compounds already found in nature, as well as disciplines like ethnopharmacology, involved in the systematic research and exploration of sources that have traditionally been used as medicine (Suntar 2020), including higher plants (Silva et al. 2019), microalgae, seaweeds (Rodriguez-Jasso et al. 2011), microorganisms (Ramkissoon et al. 2020), fungi (Heleno et al. 2016), and marine organisms (Franco et al. 2020). Plants such as Aloe vera, consisting of pseudoprototinosaponin-AIII and prototinosaponin-AIII (Shrinet et al. 2021), alkaloids, triterpenes, thiocyanates, cardiac 
Table 9 Principle, sources, compounds extracted, and process conditions used in supercritical fluid extraction

\begin{tabular}{|c|c|c|c|c|}
\hline Principle & Sources & Compounds extracted & Process conditions & References \\
\hline \multirow{9}{*}{$\begin{array}{l}\text { Separating extract from the } \\
\text { matrix using supercritical } \\
\text { fluids like } \mathrm{scCO}_{2}\end{array}$} & Mentha spicata & Flavonoids (luteolin) & $\begin{array}{l}\mathrm{scCO}_{2} \text {, pressure: } 200 \mathrm{bar}, \\
60^{\circ} \mathrm{C} \text {, and } 60 \mathrm{~min}\end{array}$ & Puri et al. 2012 \\
\hline & Feijoa leaf & $\begin{array}{l}\text { Gallic acid, catechin, and } \\
\text { isoquercetin }\end{array}$ & $\begin{array}{l}\mathrm{scCO}_{2}, 15 \% \text { ethanol-water } \\
\text { (as cosolvent), } 210 \mathrm{~min}, \\
\text { pressure: } 30 \mathrm{MPa} \text {, and } \\
55^{\circ} \mathrm{C}\end{array}$ & Santos et al.. 2021 \\
\hline & Underutilized Chia seeds & $\begin{array}{l}\text { Omega 3-rich oils (ALA } \\
\text { and linoleic acid) }\end{array}$ & $\begin{array}{l}\mathrm{scCO}_{2} \text {, pressure: } 45 \mathrm{MPa} \\
60{ }^{\circ} \mathrm{C}, 240 \mathrm{~min} \text {, and } 40 \mathrm{~g} / \\
\min \end{array}$ & Villanueva-Bermejo 2019 \\
\hline & Leaves of piper amalago & Pyrrolidine & $\begin{array}{l}\mathrm{scCO}_{2} \text {, Co-solvents: } \\
\text { ethanol, methanol, and } \\
\text { propylene glycol } 5 \% \\
\text { (v/v), pressure: } 150,200, \\
\text { and } 250 \text { bar, } 40,50 \text {, and } \\
60^{\circ} \mathrm{C}, 20,40 \text {, and } 60 \mathrm{~min}, \\
\mathrm{CO}_{2} \text { flow rate: } 3 \mathrm{~mL} / \\
\text { min, and particle size: } \\
0.757 \mathrm{~mm}\end{array}$ & $\begin{array}{l}\text { Uwineza and Waskiewicz } \\
2020\end{array}$ \\
\hline & Catharanthus roseus & Vinblastine and vincristine & $\begin{array}{l}\mathrm{scCO}_{2} \text {, Co-S: ethanol 2, } 5 \\
\text { and } 10 \%(\mathrm{v} / \mathrm{v}) \text {, pressure: } \\
300 \text { bar T: } 40,50 \text {, and } \\
60{ }^{\circ} \mathrm{C}\end{array}$ & \\
\hline & Artemisia annua $L$ & Artemisinin & $\begin{array}{l}\mathrm{scCO}_{2} \text {, pressure: } 100 \mathrm{bar}, \\
40^{\circ} \mathrm{C}, \mathrm{CO}_{2} \text { flow rate: } \\
13.3-20 \mathrm{~g} / \mathrm{min}\end{array}$ & \\
\hline & Dried ivy leaves & Chlorophyll & $\begin{array}{l}\mathrm{scCO}_{2}, \mathrm{Co}-\mathrm{S}: \text { ethanol } \\
(80 / 20 \mathrm{v} / \mathrm{v}), 25^{\circ} \mathrm{C}, \text { pres- } \\
\text { sure: } 15 \mathrm{MPa} \text {, and } 30 \mathrm{~min}\end{array}$ & Lefebvre et al. 2021 \\
\hline & Haematococcus pluvialis & Astaxanthin & $\begin{array}{l}\mathrm{scCO}_{2}, 50{ }^{\circ} \mathrm{C} \text {, pressure: } \\
50 \mathrm{MPa}, 175 \mathrm{~min} \text {, and } \\
\text { flow rate: } 2 \mathrm{~L} / \mathrm{min}\end{array}$ & Álvarez et al. 2020 \\
\hline & Rana chensinensis ovum & $\begin{array}{l}\text { Rana chensinensis ovum } \\
\text { oil (eicosapentaenoic } \\
\text { acid, } \alpha \text {-linolenic acid, } \\
\text { docosahexaenoic acid, } \\
\text { arachidonic acid, linoleic } \\
\text { acid, and oleic acid) }\end{array}$ & $\begin{array}{l}\mathrm{scCO}_{2} \text {, pressure: } 29 \mathrm{MPa} \text {, } \\
\text { flow: } 82 \mathrm{~L} / \mathrm{h}, 50^{\circ} \mathrm{C} \text {, and } \\
132 \mathrm{~min}\end{array}$ & Gan et al. 2020 \\
\hline
\end{tabular}

glycosides, and cyanogenic glycosides, among others, extracted from Terminalia catappa (Behl and Kotwani 2017) as well as Steviol glycosides in Stevia rebaudiana leaves (Zlabur et al. 2015), have antidiabetic properties. Baicalein, a flavone obtained from the dried roots of $S$. baicalensis Georgi, is known for its anti-cancer and antiinflammatory activities and has been used to treat several gastrointestinal ailments such as gastric ulceration, liver fibrosis, and so on (Xie et al. 2019). Comparable properties have been observed in silymarin (treatment of liver disorders as well as antitumor activity), extracted from Silybum marianum L. Gaertner (Wianowska and Wiśniewski 2015). The extracts of Anthemis cotula L. (stinking chamomile) were found to have potential in the treatment of Alzheimer's disease and skin hyperpigmentation conditions (Sut et al. 2019). Nutraceuticals such as quercetin and kaempferol have also been employed for managing similar neurodegenerative disorders (Makkar et al. 2020).

Other extremely important sources of bioactive compounds include algae as well as marine organisms. Fucose-sulfated polysaccharides, extracted from brown algae such as A. nodosum and Fucus vesiculosus, have been proven to be beneficial antioxidants and anticoagulants (Garcia-Vaquero et al. 2020), in addition to being antiinflammatory and antiviral (Rodriguez-Jasso et al. 2011). Fucus vesiculosus is also rich in phlorotannins, used in the treatment of goiter, obesity, rheumatoid arthritis, asthma, etc. (Catarino et al. 2019). The extracts of Chondrus crispus and Codium fragile have successfully exhibited activity against the Herpes simplex virus (HSV) (Kulshreshtha et al. 2015). 

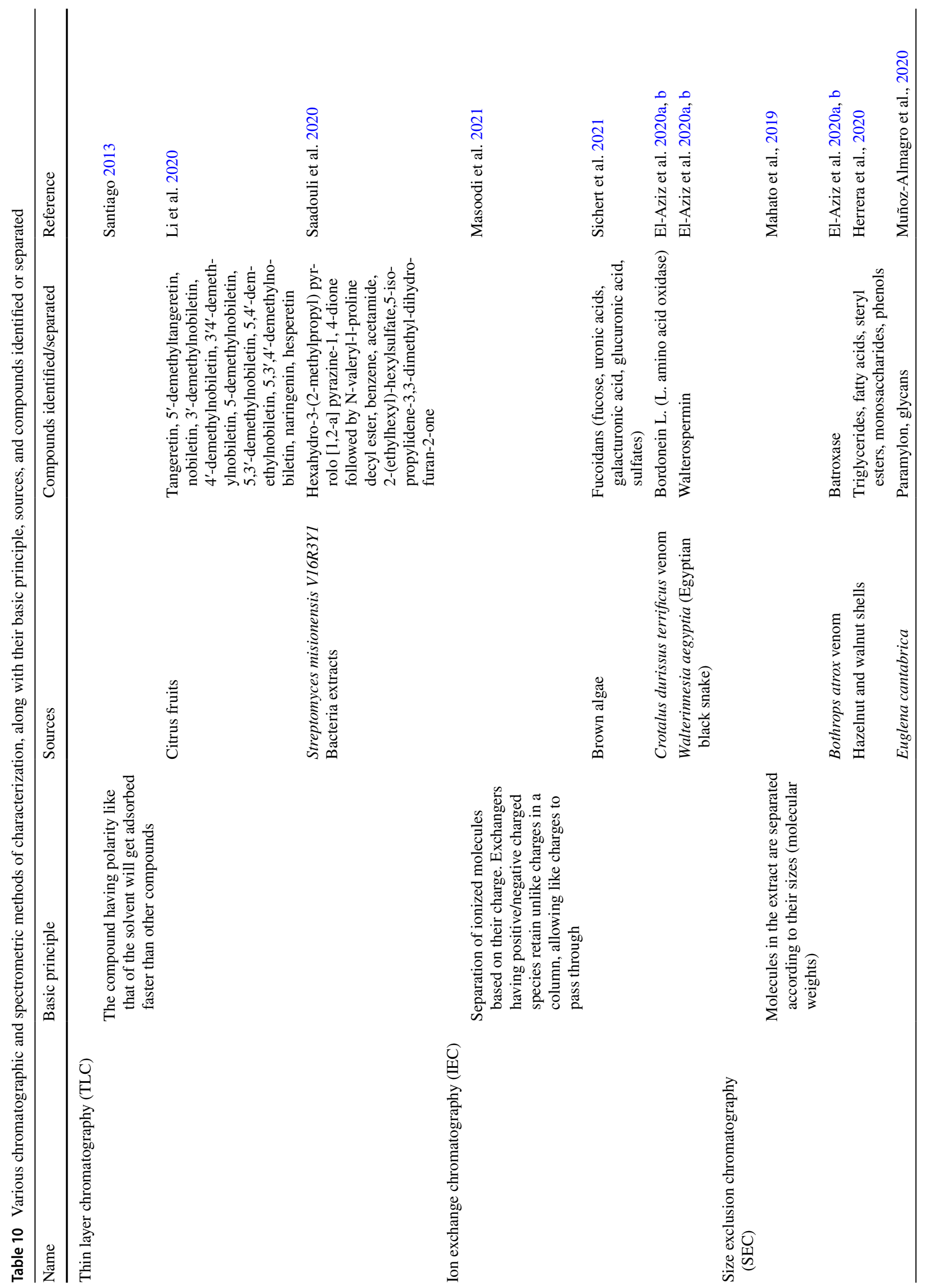


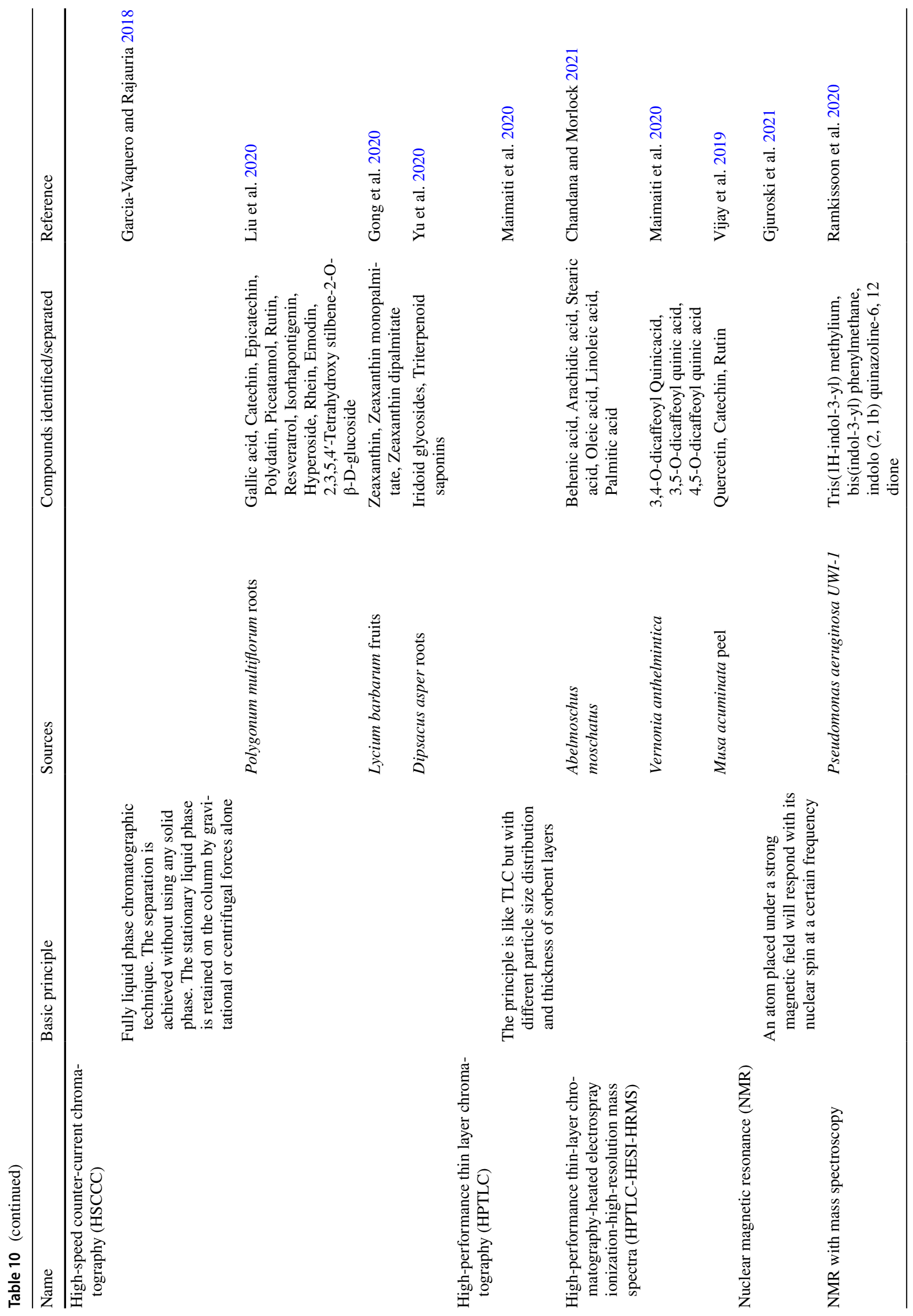




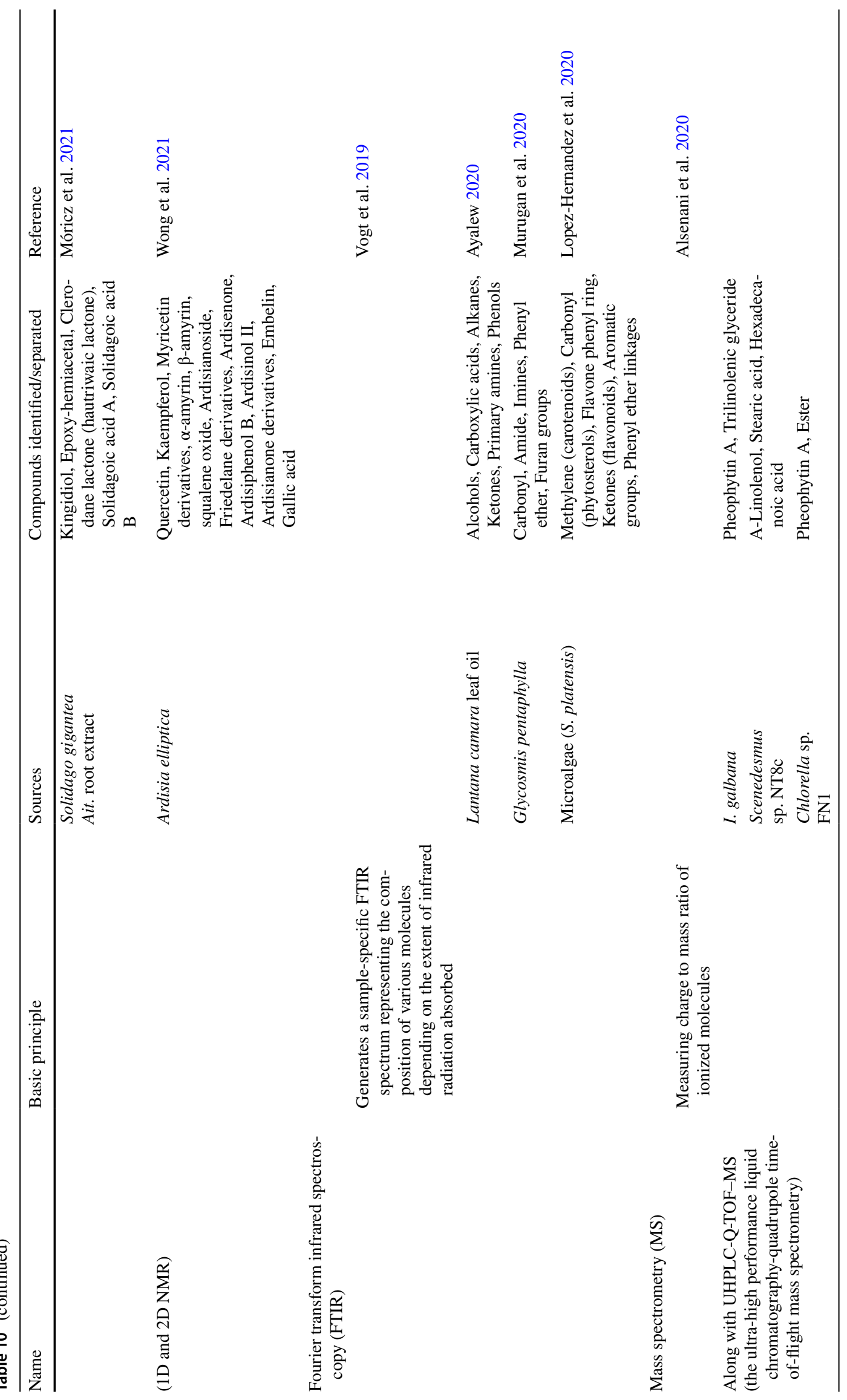




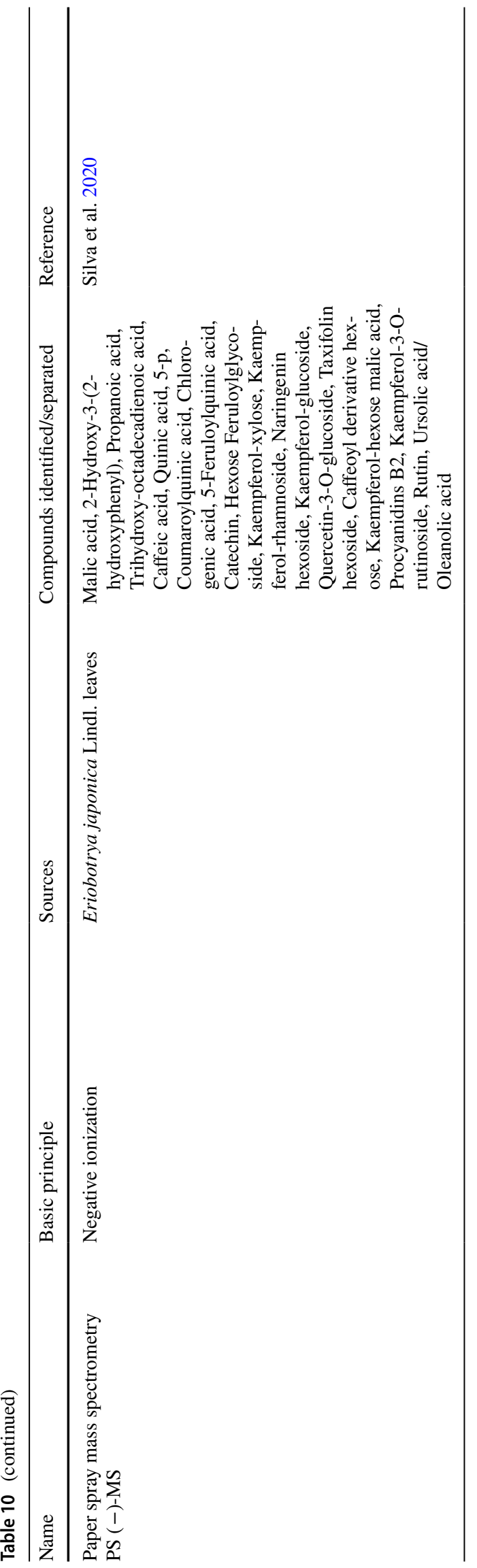

Research on bacterial and fungal bioactive compounds has explored antimicrobial and anti-cancer properties (Sinha and Hader 2021). Fungi are sources of the very first antibiotics, such as penicillins, carbapenems, and cephalosporins. Compactin and lovastatin have been very instrumental as cholesterol-lowering agents (Hoeksma et al. 2019). Bioactives obtained from fungal sources were found to exhibit antibacterial, antiviral, anti-cancer properties in addition to being immunostimulants (Poojary et al. 2017). Several indole alkaloid compounds have been extracted from bacteria such as Pseudomonas aeruginosa UWI-1 having antibiotic potential (Ramkissoon et al. 2020). Scleritodermin A, a compound isolated from Scleritoderma nodosum, was found to be effective in the treatment of human colon, breast, and ovarian tumors (Sinha and Hader 2021).

Various bioactive compounds of pharmaceutical importance have been extracted from animal sources as well. Franco et al. (2020) suggested using residues of sea bream and sea bass (gills, head, bones) to extract high-value antioxidants. Rana chensinensis ovum oil was found to have beneficial unsaturated fatty acids, instrumental in the prevention of cardiovascular as well as cerebrovascular diseases (Gan et al. 2020). Advances in venomics have helped in the extraction and isolation of animal (snake) venom, useful in the drug discovery and development of antivenom (El-Aziz et al. 2020a, b). A range of sources along with relevant compounds, many of which are of pharmaceutical interest, have already been listed in Tables 1-10.

\section{Bioremediation sector}

Bioactive compounds have found a range of applications in bioremediation sectors as well, in the form of coagulants (Ibrahim et al. 2021), biofilms (Mugge et al. 2021), bioactive extracts (Zerrifi et al. 2018), and so on. A wide range of bioactive compounds obtained from various sources has shown promising activity against harmful algal blooms (HAB), including $\alpha$-linolenic, oleic, and palmitic acids from Botryococcus braunii, diethyl phthalate from Stoechospermum marginatum, and so on (Zerrifi et al. 2018, 2021). Similarly, bioaccumulation of nutrients, as well as metals $(\mathrm{Cd}, \mathrm{Cu}, \mathrm{Zn}$, $\mathrm{Pb}, \mathrm{Cr}$ ) by Sargassum, has triple benefits in terms of reducing eutrophication and coastal metal pollution in addition to sequestering metals and useful bioactive compounds which could then be used in pharmaceutical, cosmetic, food, and fertilizer industries (Saldarriaga-Hernandez et al. 2020). d'Errico et al. (2020) reported the capability of a fungal endophyte, Drechslera (strain 678) to have dual functions as a biopesticide, due to the presence of compounds such as monocerin, as well as for bioremediation of methyl tert-butyl ether, a soil contaminant, usually used as a gasoline additive.

Tannins have also been widely used in wastewater treatment plants. Tannin-based coagulants have been employed 
to remove turbidity and flocculate suspended solids (Ibrahim et al. 2021). Condensed tannins sourced from Acacia mearnsii and tannic acid have been used to remove both cationic and anionic dyes from water (Grenda et al. 2020). Das et al. (2020) have also reviewed the use of tannin cryogels and wattle tannins in the removal of heavy metals and methylene blue, respectively, from contaminated water.

Biofilms formed by marine and intertidal bacteria have a lot of potential in bioremediation. Mugge et al. (2021) studied the changes in bacterial populations and biofilm compositions in surface and deep-sea water when exposed to crude oil or chemical dispersants, which is promising in the management and clean-up of oil spills. Lipopeptides obtained from Bacillus subtilis CN2 showed interesting properties about the degradation of polycyclic aromatic hydrocarbons and recovery of motor oil from contaminated soil (Bezza and Chirwa 2015). Hence, bioactive compounds are promising when it comes to areas like wastewater treatment and hydrocarbon degradation.

\section{Energy sector}

With the upsurge in human population, renewable energy like biofuels and other sustainable practices has become essential. Five billion tonnes of biomass waste are produced in the food and agroforestry industry. It has ample potential in the production of bioactive compounds which can be utilized as biofuels to reduce biomass waste. Ethanol and vegetable oil are widely produced as biofuels in biorefineries (Ferreira-Santos et al. 2020). Gorte et al. (2020) demonstrated pulse electric field treatment to extract lipids from fresh oleaginous yeast cells. Single-cell oils or microbial oils that are extracted from yeasts, fungi, microalgae, and bacteria can be utilized as alternative fuels, although the extraction process is expensive and not efficient. These remain as the major drawbacks still left to tackle. $C$. camphora is a potential renewable energy source, and the mass production along with the volatile constituents (camphor, eucalyptol, limonene, $\beta$-pinene) has been studied (Zhang et al., 2020a, b). Additionally, sugar-based waste (sugar cane, sugar beets), animal waste (cow, swine, poultry), food industry waste, starch-based wastes (corn), lignocellulosic waste (switchgrass, micanthus, corn stover, corn fiber), and glycerine serve as sources of bioenergy and biofuels such as ethanol, methanol, and butanol (Swain 2017). Microbial fuel cells (MFCs) use microbes to generate electricity. They have shown enhanced power density with electron shunting capabilities of a few secondary metabolites such as epigallocatechin-3-gallate, gallic acid, gallocatechin, and anthocyanin. The addition of fungal and algal metabolites in the MFCs improves electricity production (Nath and Ghangrekar 2020). Condensation of $\beta$-pinene is processed to form dimers which is an excellent option for a renewable and high energy-density jet fuel and can also be used as diesel (Jung et al. 2016). Effects of a dual biofuel blend consisting of different concentrations of jatropha biodiesel and turpentine oil were studied in a single-cylinder diesel engine and are a cost-effective alternative for fossil fuels. There was a reduction in carbon monoxide, hydrocarbon, and nitrous oxide emissions by $13.04 \%, 17.5 \%$, and $4.21 \%$, respectively, but an increase in $\mathrm{CO}_{2}$ emissions by $11.04 \%$ (Dubey and Gupta 2018).

\section{Chemical sector}

Bioactive compounds have applications in various chemical industries, including but not limited to polymers and biomaterials (Nogueira et al. 2020), dyes and textiles (Agnhage et al. 2017), leather processing (Das et al. 2020), perfumes, and cosmetics (Sharmeen et al. 2021). Certain bioactive compounds (oils, fatty acids) have traditionally been used (in the oil and soap industries) (Ng et al. 2021), whereas the toxicity and unsustainability of conventional chemicals, processes, or end-products have recently accelerated the usage of bio-based substitutes in novel materials, catalysts, as and certain raw materials in the industry (Chin et al. 2021; Basak et al. 2021).

Spiridon et al. (2020) developed a biomaterial with cellulose, collagen, and polyurethane as its constituents, to facilitate the controlled release of antioxidants such as tannin and lipoic acid, with a potential for biomedical and cosmetic applications. Similar approaches of encapsulation of antioxidants were carried out using Aloe vera agrowastes, by incorporating them into electro spun nanofibers made from polyethylene oxide (Solaberrieta et al. 2020). These technologies have also enabled the development of biodegradable and even edible food packaging films with enhanced antimicrobial, antioxidant, and mechanical properties, achieved by a combination of biopolymers (starch, chitosan, gluten) and bioactive (essential oils, polyphenols, carotenoids) (Nogueira et al. 2020). Other interesting properties, such as flame retardancy, antibacterial, and UV light protection in textiles have been achieved by using tannin-based macromolecules (Basak et al. 2021). Dyes, such as the run dye from the core stem tissues of Miscanthus sinensis Andersson (Pinzon et al. 2020) and naturally sourced anthraquinone dyes from the roots of Rubia tinctorum L. (Agnhage et al. 2017), have also been produced.

Various essential oils such as lavender, carvone, linalool, limonene, citronellol, and eucalyptus are popular choices in the perfume and cosmetic industry. In addition to fragrance, they also act as preservatives and active ingredients and have beneficial effects on the skin (Sharmeen et al. 2021). Phlorotannins, polysaccharides (laminarin, carrageenan, etc.), astaxanthin, and several bioactive peptides present in seaweed and microalgae have been reported as excellent sources for 
cosmeceuticals due to their anti-aging, anti-acne, antimicrobial, skin glow enhancement, moisture retention, UV protection, and anti-allergic properties (Jesumani et al. 2019).

The industrial extraction of oils (palm, coconut, and castor oils) is another important sector of the chemical industry, due to a wide range of applications, ranging from edible oils and hair care products (Ng et al. 2021) to the manufacture of soaps and grease (Patel et al. 2016). Moreover, several petrochemical industries in Malaysia are looking into the possibility of using palm oil as well as glycerol sourced from vegetable oil as feedstocks in the manufacture of lubricants (Chin et al. 2021), shifting resources from fossil fuels to bioactive compounds. Similarly, castor oils are used in the manufacture of biodegradable polyesters as well as lubricants and paints (Patel et al. 2016).

Tannins, on the other hand, are widely abundant and industrially important bioactive compounds that have been used in the leather processing and wood (adhesive and preservation) industry for centuries (Das et al. 2020). In addition to this, several novels and sustainable alternatives to 3D printing (Liao et al. 2020) using tannins have been explored. Bioactive compounds thus have a high potential for creating a sustainable chemical industry if measures are taken for efficient extraction and conservation of biodiversity.

\section{Limitations}

Conventional extraction processes are helpful; however, they are inefficient and time-consuming. To overcome the said limitations, non-conventional extraction methods have been designed. However, they have certain demerits as well. Susceptibility of thermosensitive compounds, nonuniformity of extraction in large-scale industries, and high maintenance costs and $\mathrm{CO}_{2}$ consumption leading to highvalue compounds are the challenges faced in UAE, MAE, and SFE, respectively. For example, in the case of SFE, astaxanthin and phycobiliproteins in microalgae are high-value compounds due to the expensive extraction and purification processes (Roohinejad et al. 2017). Various other limitations specific to each extraction method have already been discussed.

A major impediment to the widespread use of bioactive compounds is the varying stability and loss of activity, especially in foods, as most experiments verifying beneficial properties are done under controlled conditions. Variation among individuals is also a crucial factor that must be considered while studying the nutritional and therapeutic benefits of bioactive compounds. Differences in processes such as absorption and metabolism, as well as diversity in age, gender, and lifestyles, could result in varied effects of such compounds in a population. From the ecological perspective, meeting the growing demands for bioactive compounds is bound to exert a lot of pressure on biodiversity, land, and marine resources, which could threaten the survival of exceedingly rare species.

Challenges that are frequently overlooked about bioanalytical methods of characterization are interference to a considerable extent, clean-up during sample preparation, low sensitivity, accuracy, and unreliable methods to name a few. Other aspects, such as bioavailability, bio accessibility, safe and "green" production practices, safety, and toxicology, must be considered as well, especially when downstream processes account for $50-80 \%$ of the production value (Cuellar-Bermudez et al. 2015).

\section{Future scope}

The advent of non-communicable diseases such as cancer, obesity, diabetes, and so on over the last few decades, the instances of antibiotic resistance in pathogenic microorganisms, the increased awareness for sustainable products, bioremediation efforts, and the recent pandemic have led to a spike in demand for healthier, natural, immune-boosting and bio-fortified foods, novel antibiotics and pharmaceuticals, bio-based raw materials for various processes, and biomaterials with novel functionalities. A report by Grand View Research, Inc. (2016) states that the global market size for bioactive ingredients is expected to cross USD 51.71 billion by 2024 , with functional foods and beverages contributing to $25 \%$ of the market, sourced from plants and marine organisms (https://www.grandviewresearch.com/press-release/ global-bioactive-ingredients-market). This surge in demand necessitates further research into sustainable and effective methods of screening, extraction, characterization, processing, and commercialization of good-quality bioactive compounds. Fu et al. (2019) have suggested a shift to multi-targeted approaches to screening multiple bioactive compounds simultaneously with the help of biosensor and microfluidic chip-based technologies, as opposed to conventional chromatographic methods. The mechanism of action of bioactive compounds in certain cases is best understood during in vivo screening methods; hence, the scope of discovery of these compounds is limited when screening is confined to in vitro assays (Ahamefule et al. 2020). Designing effective in vivo assays, especially for antibiotic activity, could help in screening such compounds utilizing novel mechanisms. Ways to improve selectivity and yield of extraction, such as modeling solvent-compound interactions and affinities, as well as optimization of physical parameters in case of nonconventional methods must be explored further to decrease costs and facilitate scalability.

Metabolic engineering is a potential tool to facilitate microbial production of bioactive compounds such as terpenoids, omega-3 PUFAs, and so on, to tackle the 
exploitation of rare and limited marine resources for commercial production. Other approaches of finding optimum sources from by-products of food processing industries and agricultural residues can help in implementing sustainable methods of waste recycling and high-value product recovery, boosting a circular economy.

Nanoencapsulation strategies have a good potential when it comes to retaining bioavailability, enhancing stability, and facilitating the controlled release of bioactive compounds while being delivered into functional food items. Encapsulation within naturally assembling structures and biopolymer films in food packaging are a few approaches. The challenge lies in making them economically viable alternatives to conventional solutions.

\section{Conclusion}

This article has reviewed bioactive compounds, their extraction methods, characterization methods, applications, limitations, and future scope, all together. The popular conventional and non-conventional extraction methods to extract bioactive compounds along with tables containing the basic principles, sources, latest compounds extracted, solvent or enzymes used, and process conditions were reviewed and listed. Bio-analytical characterization methods were elucidated with the help of a table. The applications of bioactive compounds in the food, pharmaceutical, bioremediation, energy, and chemical sectors were documented diffusely. Moreover, the limitations and challenges faced in the extraction and characterization processes were compiled. The prospects of the bioactive compounds were put together considering the ongoing pandemic situation although it needs further investigation. This gives an insight into the value of bioactive compounds from the perspective of human health and the sustainability of global resources. As the technology ameliorates, the potential of bioactive compounds in various sectors is bound to escalate, thus unlocking new possibilities.

Acknowledgements The authors thank the authorities of Manipal Institute of Technology, Manipal, Karnataka, India, for their support in carrying out this work.

Author contribution SP and AH contributed to the literature collection, analyzed data, and wrote the original draft. SS designed and supervised the study and was also involved in drafting the manuscript. All authors read and approved the final manuscript.

Funding Open access funding provided by Manipal Academy of Higher Education, Manipal.

Data availability The datasets used and/or analyzed during the current study are available from the corresponding author on reasonable request.

\section{Declarations}

Ethics approval and consent to participate Not applicable.

Consent for publication Not applicable.

Competing interests The authors declare no competing interests.

Open Access This article is licensed under a Creative Commons Attribution 4.0 International License, which permits use, sharing, adaptation, distribution and reproduction in any medium or format, as long as you give appropriate credit to the original author(s) and the source, provide a link to the Creative Commons licence, and indicate if changes were made. The images or other third party material in this article are included in the article's Creative Commons licence, unless indicated otherwise in a credit line to the material. If material is not included in the article's Creative Commons licence and your intended use is not permitted by statutory regulation or exceeds the permitted use, you will need to obtain permission directly from the copyright holder. To view a copy of this licence, visit http://creativecommons.org/licenses/by/4.0/.

\section{References}

Agnhage T, Zhou Y, Guan J, Chen G, Perwuelz A, Behary N, Nierstrasz V (2017) Bioactive and multifunctional textile using plantbased madder dye: characterization of UV protection ability and antibacterial activity. Fibers Polym 18(11):2170-2175. https:// doi.org/10.1007/s12221-017-7115-x

Ahamefule CS, Ezeuduji BC, Ogbonna JC, Moneke AN, Ike AC, Wang B, Jin C, Fang W (2020) Marine bioactive compounds against Aspergillus fumigatus: challenges and future prospects. Antibiotics 9(11):813. https://doi.org/10.3390/antibiotics9110813

Al Jitan S, Alkhoori SA, Yousef LF (2018) Phenolic acids from plants: extraction and application to human health. Stud Nat Prod Chem 58:389-417. https://doi.org/10.1016/B978-0-444-64056-7.00013-1

Alsenani F, Tupally KR, Chua ET, Eltanahy E, Alsufyani H, Parekh HS, Schenk PM (2020) Evaluation of microalgae and cyanobacteria as potential sources of antimicrobial compounds. Saudi Pharm J 28(12):1834-1841. https://doi.org/10.1016/j.jsps.2020. 11.010

Álvarez EC, Vardanega R, Salinas-Fuentes F, Ramírez PJ, Muñoz BW, Jiménez-Rondón D, Meireles MAA, Mezquita CP, RuizDomínguez MC (2020) Effect of $\mathrm{CO}_{2}$ flow rate on the extraction of astaxanthin and fatty acids from Haematococcus pluvialis using supercritical fluid technology. Molecules 25(24):6044. https://doi.org/10.3390/molecules25246044

Anticona M, Blesa J, Frigola A, Esteve MJ (2020) High biological value compounds extraction from citrus waste with non-conventional methods. Foods 9(6):811. https://doi.org/10.3390/foods9060811

Ayalew AA (2020). Chromatographic and spectroscopic determination of solvent-extracted Lantana camara leaf oil. Int J Med Res 48(10). https://doi.org/10.1177/0300060520962344

Azmir J, Sarker MZ, Rahman M, Khan MS, Awang M, Ferdosh S, Jahurul MHA, Ghafoor K, Norulaini NAN, Omar AKM (2013) Techniques for extraction of bioactive compounds from plant materials: a review. J Food Eng 117(4):426-436. https://doi.org/ 10.1016/j.jfoodeng.2013.01.014

Basak S, Raja ASM, Saxena S, Patil PG (2021) Tannin based polyphenolic bio-macromolecules: creating a new era towards sustainable flame retardancy of polymers. Polym Degrad Stab 189. https://doi.org/10.1016/j.polymdegradstab.2021.109603 
Baysal T, Ersus S, Starmans DAJ (2000) Supercritical CO2 extraction of $\beta$-carotene and lycopene from tomato paste waste. J Agric Food Chem 48(11):5507-5511. https://doi.org/10.1021/jf000 $311 \mathrm{t}$

Behl T, Kotwani A (2017) Proposed mechanisms of Terminalia catappa in hyperglycemia and associated diabetic complications. $\mathrm{J}$ Pharm Pharmacol 69(2):123-134. https://doi.org/10.1111/jphp. 12676

Bezza FA, Chirwa EMN (2015) Production and applications of lipopeptide biosurfactant for bioremediation and oil recovery by Bacillus subtilis CN2. Biochem Eng J 101:168-178. https://doi. org/10.1016/j.bej.2015.05.007

Bioactive Ingredient Market Size Worth \$51.71 Billion By 2024 (2016). https://www.grandviewresearch.com/press-release/ global-bioactive-ingredients-market. Accessed 18 August 2021.

Bozinou E, Karageorgou I, Batra G, Dourtoglou VG, Lalas SI (2019) Pulsed electric field extraction and antioxidant activity determination of moringa oleifera dry leaves: a comparative study with other extraction techniques. Beverages 5(1):8. https://doi.org/10. 3390/beverages 5010008

Câmara JS, Albuquerque BR, Aguiar J, Corrêa R, Gonçalves JL, Granato D, Pereira J, Barros L, Ferreira I (2020) Food bioactive compounds and emerging techniques for their extraction: polyphenols as a case study. Foods 10(1):37. https://doi.org/10.3390/ foods 10010037

Cao-Ngoc P et al (2020) Water-based extraction of bioactive principles from blackcurrant leaves and Chrysanthellum americanum: a comparative study. Foods 9(10):1478. https://doi.org/10.3390/ foods 9101478

Capuzzo A, Maffei ME, Occhipinti A (2013) Supercritical fluid extraction of plant flavors and fragrances. Molecules 18(6):7194-7238. https://doi.org/10.3390/molecules 18067194

Carullo D, Pataro G, Donsì F, Ferrari G (2020). Pulsed electric fieldsassisted extraction of valuable compounds from Arthrospira Platensis: effect of pulse polarity and mild heating. Front Bioeng Biotechnol 8. https://doi.org/10.3389/fbioe.2020.551272

Castro-Puyana M et al (2017) Pressurized liquid extraction of Neochloris oleoabundans for the recovery of bioactive carotenoids with anti-proliferative activity against human colon cancer cells. Food Res Int 99:1048-1055. https://doi.org/10.1016/j.foodres. 2016.05.021

Catarino MD, Silva AMS, Mateus N, Cardoso SM (2019) Optimization of phlorotannins extraction from Fucus vesiculosus and evaluation of their potential to prevent metabolic disorders. Mar Drugs 17(3):162. https://doi.org/10.3390/md17030162

Chakraborty S, Uppaluri R, Das C (2020) Optimization of ultrasoundassisted extraction (UAE) process for the recovery of bioactive compounds from bitter gourd using response surface methodology (RSM). Food Bioproduct Process 120:114-122. https://doi. org/10.1016/j.fbp.2020.01.003

Chandana NGASS, \& Morlock GE (2021) Comprehensive bioanalytical multi-imaging by planar chromatography in situ combined with biological and biochemical assays highlights bioactive fatty acids in abelmosk. Talanta 223. https://doi.org/10.1016/j.talan ta.2020.121701

Chang CW, Yen CC, Wu MT, Hsu MC, Wu YT (2017) Microwaveassisted extraction of cannabinoids in hemp nut using response surface methodology: optimization and comparative study. Molecules 22(11):1894. https://doi.org/10.3390/molecules22111894

Chhikara N, Kushwaha K, Sharma P, Gat Y, Panghal A (2019) Bioactive compounds of beetroot and utilization in food processing industry: a critical review. Food Chem 272:192-200. https://doi. org/10.1016/j.foodchem.2018.08.022

Chin SY, Shahruddin S, Chua GK, Samsodin N, Setiabudi HD, Karam Chand NS, Chew FN, Leong JX, Jusoh R, Samsudin NA (2021)
Palm oil-based chemicals for sustainable development of petrochemical industries in Malaysia: progress, prospect, and challenges. ACS Sustain Chem Eng 9(19):6510-6533. https://doi. org/10.1021/acssuschemeng.0c09329

Cuellar-Bermudez SP, Cardenas-Chavez A-H, DL, Ornelas-Soto N, Romero-Ogawa MA, Parra-Saldivar R, (2015) Extraction and purification of high-value metabolites from microalgae: essential lipids, astaxanthin, and phycobiliproteins. Microb Biotechnol 8(2):190-209. https://doi.org/10.1111/1751-7915.12167

d'Errico G, Aloj V, Flematti GR, Sivasithamparam K, Worth CM, Lombardi N, Ritieni A, Marra R, Lorito M, Vinale F (2020) Metabolites of a Drechslera sp. endophyte with potential as biocontrol and bioremediation agent. Nat Prod Res https://doi.org/ 10.1080/14786419.2020.1737058

Das AK, Islam MN, Faruk MO, Ashaduzzaman M, Dungani R (2020) Review on tannins: extraction processes, applications, and possibilities. S Af J Bot 135:58-70. https://doi.org/10.1016/j.sajb.2020.08.008

Das S, Ray A, Nasim N, Nayak S, Mohanty S (2019) Effect of different extraction techniques on total phenolic and flavonoid contents, and antioxidant activity of betelvine and quantification of its phenolic constituents by validated HPTLC method. 3 Biotech, 9(1):37. https://doi.org/10.1007/s13205-018-1565-8

Dubey P, Gupta R (2018) Influences of dual biofuel (Jatropha biodiesel and turpentine oil) on single cylinder variable compression ratio diesel engine. Renew Energy 115:1294-1302. https://doi.org/10. 1016/j.renene.2017.09.055

El-Aziz TMA, Jaquillard L, Bourgoin-Voillard S, Martinez G, Triquigneaux M, Zoukimian C, Combemale S, Hograindleur JP, al Khoury S, Escoffier J, Michell and S, Bulet P, Beroud R, Seve M, Arnoult C, de Waard M, (2020a) Identification, characterization and synthesis of walterospermin, a sperm motility activator from the Egyptian black snake Walterinnesia aegyptia venom. Int J Mol Sci 21(20):7786. https://doi.org/10.3390/ijms21207786

El-Aziz TMA, Soares AG, Stockand JD (2020b) Advances in venomics: modern separation techniques and mass spectrometry. In J Chromatogr B 1160. https://doi.org/10.1016/j.jchromb.2020.122352

Esclapez MD, García-Pérez JV, Mulet A, Carcel JA (2011) Ultrasoundassisted extraction of natural products. Food Eng Rev 3:108. https://doi.org/10.1007/s12393-011-9036-6

Ferreira-Santos P, Zanuso E, Genisheva Z, Rocha CMR, Teixeira JA (2020) Green and sustainable valorization of bioactive phenolic compounds from pinus by-products. Molecules 25(12):2931. https://doi.org/10.3390/molecules25122931

Franco D, Munekata P, Agregan R, Bermudez R, Lopez-Pedrouso M, Pateiro M, Lorenzo JM (2020) Application of pulsed electric fields for obtaining antioxidant extracts from fish residues. Antioxidants 9(2):90. https://doi.org/10.3390/antiox 9020090

$\mathrm{Fu} \mathrm{Y,} \mathrm{Luo} \mathrm{J,} \mathrm{Qin} \mathrm{J,} \mathrm{Yang} \mathrm{M} \mathrm{(2019)} \mathrm{Screening} \mathrm{techniques} \mathrm{for} \mathrm{the}$ identification of bioactive compounds in natural products. $\mathrm{J}$ Pharm Biomed Anal 168:189-200. https://doi.org/10.1016/j. jpba.2019.02.027

Gan Y, Xu D, Zhang J, Wang Z, Wang S, Guo H, Zhang K, Li Y, Wang Y (2020) Rana chensinensis ovum oil based on $\mathrm{CO}_{2}$ supercritical fluid extraction: response surface methodology optimization and unsaturated fatty acid ingredient analysis. Molecules 25(18):4170. https://doi.org/10.3390/molecules25184170

García-Vaquero M, Rajauria G (2018). Analytical techniques for phytochemical estimation in fruit juices. In: Fruit juices: extraction, composition, quality and analysis. Elsevier Inc. pp 669-692. https://doi.org/10.1016/B978-0-12-802230-6.00033-3

Garcia-Vaquero M, Ummat V, Tiwari B, Rajauria G (2020) Exploring ultrasound, microwave and ultrasound-microwave assisted extraction technologies to increase the extraction of bioactive compounds and antioxidants from brown macroalgae. Mar Drugs 18(3):172. https://doi.org/10.3390/md18030172 
Gjuroski I, Furrer J, Vermathen M (2021) Probing the interactions of porphyrins with macromolecules using NMR spectroscopy techniques. Molecules 26(7)1942. https://doi.org/10.3390/molec ules26071942

Gong Y, Huang XY, Liu JF, Pei D, Duan W da, Zhang X, Sun X, Di DL (2020) Effective online high-speed shear dispersing emulsifier technique coupled with high-performance countercurrent chromatography method for simultaneous extraction and isolation of carotenoids from Lycium barbarum $L$. fruits. J Sep Sci 43(14):2949-2958. https://doi.org/10.1002/jssc.202000215

Gonzalez M, Barrios S, Budelli E, Pérez N, Lema P, Heinzen H (2020) Ultrasound assisted extraction of bioactive compounds in fresh and freeze-dried Vitis vinifera cv Tannat grape pomace. Food Bioproduct Process 124:378-386. https://doi.org/10.1016/j.fbp.2020.09.012

Gorte O, Nazarova N, Papachristou I, Wustner R, Leber K, Syldatk C, Ochsenreither K, Frey W, Silve A (2020). Pulsed electric field treatment promotes lipid extraction on fresh oleaginous yeast Saitozyma podzolica DSM 27192. Front Bioeng Biotechnol 8. https://doi.org/10.3389/fbioe.2020.575379

Grenda K, Arnold J, Gamelas JAF, Rasteiro MG (2020) Up-scaling of tannin-based coagulants for wastewater treatment: performance in a water treatment plant. Environ Sci Pollut Res 27(2):12021213. https://doi.org/10.1007/s11356-018-2570-5

Gwaltney-Brant SM (2021) Nutraceuticals in hepatic diseases. In: Nutraceuticals: efficacy, safety and toxicity, 2nd edn. Elsevier Inc. pp 117-129. https://doi.org/10.1016/B978-0-12-821038-3.00008-2

Habibi H, Khosravi-Darani K (2017) Effective variables on production and structure of xanthan gum and its food applications: a review. Biocatal Agric Biotechnol 10:130-140. https://doi.org/10.1016/j. bcab.2017.02.013

Hashemi Gahruie H, Parastouei K, Mokhtarian M, Rostami H, Niakousari M, Mohsenpour Z (2020) Application of innovative processing methods for the extraction of bioactive compounds from saffron (Crocus sativus) petals. J Appl Res Med Aromat Plants 19. https://doi.org/10.1016/j.jarmap.2020.100264

Heleno SA, Diz P, Prieto MA, Barros L, Rodrigues A, Barreiro MF, Ferreira IC (2016) Optimization of ultrasound-assisted extraction to obtain mycosterols from Agaricus bisporus $L$. by response surface methodology and comparison with conventional Soxhlet extraction. Food Chem 197(B):1054-1063. https://doi.org/ 10.1016/j.foodchem.2015.11.108

Herrera R, Hemming J, Smeds A, Gordobil O, Willför S, Labidi J (2020) Recovery of bioactive compounds from hazelnuts and walnuts shells: quantitative-qualitative analysis and chromatographic purification. Biomolecules 10(10):1363. https://doi.org/ 10.3390/biom 10101363

Hirondart M, Rombaut N, Fabiano-Tixier AS, Bily A, Chemat F (2020) Comparison between pressurized liquid extraction and conventional Soxhlet extraction for rosemary antioxidants, yield, composition, and environmental footprint. Foods 9(5):584. https:// doi.org/10.3390/foods 9050584

Hmidani A, Bouhlali E dine T, Khouya T, Ramchoun M, Filali-zegzouti Y, Benlyas M, Alem C (2019) Effect of extraction methods on antioxidant and anticoagulant activities of Thymus atlanticus aerial part. Sci Afr 5. https://doi.org/10.1016/j.sciaf.2019.e00143

Hoeksma J, Misset T, Wever C, Kemmink J, Kruijtzer J, Versluis K, Liskamp RMJ, Boons GJ, Heck AJR, Boekhout T, den Hertog J (2019) A new perspective on fungal metabolites: identification of bioactive compounds from fungi using zebrafish embryogenesis as read-out. Sci Rep 9(1). https://doi.org/10.1038/ s41598-019-54127-9

Ibrahim A, Yaser AZ, Lamaming J (2021) Synthesising tannin-based coagulants for water and wastewater application: a review. J Environ Chem Eng 9(1). https://doi.org/10.1016/j.jece.2020. 105007
Jesumani V, Du H, Aslam M, Pei P, Huang N (2019) Potential use of seaweed bioactive compounds in skincare-a review. Mar Drugs 17(12):688. https://doi.org/10.3390/md17120688

Jung JK, Lee Y, Choi JW, Jae J, Ha JM, Suh DJ, Choi J, Lee KY (2016) Production of high-energy-density fuels by catalytic $\beta$-pinene dimerization: effects of the catalyst surface acidity and pore width on selective dimer production. Energy Convers Manag 116:72-79. https://doi.org/10.1016/j.enconman.2016.02.053

Karaffa L, Kubicek CP (2021) Production of organic acids by fungi. Encyclopedia of Mycology 2:406-419. https://doi.org/10.1016/ b978-0-12-809633-8.21066-2

Kazmi A, Clark J (2012) Biomass to chemicals. In: Comprehensive renewable energy, Elsevier Ltd. pp 395-410.

Kokkali M, Martí-Quijal FJ, Taroncher M, Ruiz MJ, Kousoulaki K, Barba FJ (2020) Improved extraction efficiency of antioxidant bioactive compounds from Tetraselmis chuii and Phaedoactylum tricornutum using pulsed electric fields. Molecules 25(17):3921. https://doi.org/10.3390/molecules25173921

Kulshreshtha G, Burlot AS, Marty C, Critchley A, Hafting J, Bedoux G, Bourgougnon N, Prithiviraj B (2015) Enzyme-assisted extraction of bioactive material from Chondrus crispus and Codium fragile and its effect on herpes simplex virus (HSV-1). Mar Drugs 13(1):558-580. https://doi.org/10.3390/md13010558

Kumar K, Srivastav S, Sharanagat VS (2021) Ultrasound-assisted extraction (UAE) of bioactive compounds from fruit and vegetable processing by-products: a review. Ultrason Sonochem Elsevier BV 70. https://doi.org/10.1016/j.ultsonch.2020.105325

Lefebvre T, Destandau E, Lesellier E (2021) Selective extraction of bioactive compounds from plants using recent extraction techniques: a review. J Chromatogr A 1635:461770. https://doi.org/ 10.1016/j.chroma.2020.461770

Li J, Niu D, Zhang Y, Zeng XA (2020) Physicochemical properties, antioxidant and antiproliferative activities of polysaccharides from Morinda citrifolia L. (Noni) based on different extraction methods. Int J Biol Macromol 150:114-121. https://doi.org/10. 1016/j.ijbiomac.2019.12.157

Li Y, Zhao C, Lu C, Zhou S, Tian G, He L, Bao Y, Fauconnier ML, Xiao H, Zheng J (2021). Simultaneous determination of 14 bioactive citrus flavonoids using thin-layer chromatography combined with surface-enhanced Raman spectroscopy. Food Chem 338. https://doi.org/10.1016/j.foodchem.2020.128115

Liu M, Li X, Liu Q, Xie S, Zhu F, Chen X (2020) Preparative isolation and purification of 12 main antioxidants from the roots of Polygonum multiflorum Thunb. using high-speed countercurrent chromatography and preparative HPLC guided by $1,1^{\prime}$-diphenyl2-picrylhydrazyl-HPLC. J Sep Sci 43(8):1415-1422. https://doi. org/10.1002/jssc. 201901287

López-Hernández JF, García-Alamilla P, Palma-Ramírez D, ÁlvarezGonzález CA, Paredes-Rojas JC, Márquez-Rocha FJ (2020) Continuous microalgal cultivation for antioxidants production. Molecules 25(18):4171. https://doi.org/10.3390/molecules2 5184171

Ma XD, Zhang XG, Guo SJ, Ma GY, Liu WJ, Wang N, Feng M, Su Y (2021) Application of enzyme-assisted extraction of baicalin from Scutellaria baicalensis Georgi. Prep Biochem Biotechnol 51(3):241-251. https://doi.org/10.1080/10826068.2020.1808791

Mahato N, Sinha M, Sharma K, Koteswararao R, Cho MH (2019) Modern extraction and purification techniques for obtaining high purity food-grade bioactive compounds and value-added co-products from citrus wastes. Foods 8(11):523. https://doi.org/ 10.3390/foods 8110523

Maimaiti Z, Turak A, Ma QL, Liu G, Aisa HA (2020) Quantitative determination of marker compounds and fingerprint analysis of the seeds of Vernonia anthelmintica. Int J Anal Chem 2020. https://doi.org/10.1155/2020/8859425 
Majekodunmi SO (2015) Review of extraction of medicinal plants for pharmaceutical research. Merit Res J Med Sci 3(11):521-527. Retrieved from http://www.meritresearchjournals.org/mms/ index.htm

Makkar R, Behl T, Bungau S, Zengin G, Mehta V, Uddin KA, MS, Ashraf, GM, Abdel-Daim MM, Arora S, Oancea R, (2020) Nutraceuticals in neurological disorders. Int J Mol Sci 21(12):4424. https://doi.org/10.3390/ijms21124424

Makkar R, Behl T, Kumar A, Nijhawan P, Arora S (2021) Emerging therapeutic effects of herbal plants in rheumatoid arthritis. Endocr Metab Immune Disord Drug Targets 21(4):617-625. https://doi.org/10.2174/1871530320666200620232828

Martínez JM, Delso C, Álvarez I, Raso J (2020) Pulsed electric fieldassisted extraction of valuable compounds from microorganisms. Compr Rev Food Sci Food Saf 19(2):530-552. https://doi.org/ 10.1111/1541-4337.12512

Masoodi KZ, Lone SM, Rasool RS (2021) Ion exchange chromatography. Advanced methods in molecular biology and biotechnology: a practical lab manual. Academic Press, London, pp 151-154

Mayolo-Deloisa K, González-González M, Rito-Palomares M (2020) Laccases in food industry: bioprocessing, potential industrial and biotechnological applications. Front Bioeng Biotechnol 8:222. https://doi.org/10.3389/fbioe.2020.00222

Milani G, Curci F, Cavalluzzi MM, Crupi P, Pisano I, Lentini G, Clodoveo ML, Franchini C, Corbo F (2020) Optimization of microwave-assisted extraction of antioxidants from bamboo shoots of Phyllostachys pubescens. Molecules 25(1):215. https://doi.org/ 10.3390/molecules25010215

Miller C, Fosmer A, Rush B, McMullin T, Beacom D, Suominen P (2011). Industrial production of lactic acid. In: Comprehensive Biotechnology, 2nd edn. Volume 3. Elsevier B.V. pp 179-188.

Móricz ÁM, Krüzselyi D, Ott PG, Garádi Z, Béni S, Morlock GE, Bakonyi J (2021) Bioactive clerodane diterpenes of giant goldenrod (Solidago gigantea Ait.) root extract. J Chromatogr A 1635. https://doi.org/10.1016/j.chroma.2020.461727

Muala W, Desobgo Z, Jong NE (2021) Optimization of extraction conditions of phenolic compounds from Cymbopogon citratus and evaluation of phenolics and aroma profiles of extract. Heliyon 7(4). https://doi.org/10.1016/j.heliyon.2021.e06744

Mugge RL, Salerno JL, Hamdan LJ (2021) Microbial functional responses in marine biofilms exposed to deepwater horizon spill contaminants. Front Microbiol 12. https://doi.org/10.3389/fmicb. 2021.636054

Muñoz-Almagro N, Gilbert-López B, Pozuelo-Rollón MC, GarcíaFernandez Y, Almeida C, Villamiel M, Mendiola JA, Ibáñez E (2020) Exploring the microalga Euglena cantabrica by pressurized liquid extraction to obtain bioactive compounds. Mar Drugs 18(6):308. https://doi.org/10.3390/md18060308

Murugan N, Srinivasan R, Murugan A, Kim M, Natarajan D (2020) Glycosmis pentaphylla (Rutaceae): A natural candidate for the isolation of potential bioactive arborine and skimmianine compounds for controlling multidrug-resistant Staphylococcus aureus. Front Public Health 8:176. https://doi.org/10.3389/fpubh. 2020.00176

Mussatto SI (2015) Generating biomedical polyphenolic compounds from spent coffee or silverskin. In: Coffee in health and disease prevention, Elsevier Inc. pp 93-106. https://doi.org/10.1016/ B978-0-12-409517-5.00011-5

Nadar SS, Rao P, Rathod VK (2018) Enzyme assisted extraction of biomolecules as an approach to novel extraction technology: a review. Food Res Int Elsevier Ltd 108:309-330. https://doi.org/ 10.1016/j.foodres.2018.03.006

Nath D, Ghangrekar MM (2020) Plant secondary metabolites induced electron flux in microbial fuel cell: investigation from laboratory-to-field scale. Sci Rep 10(1). https://doi.org/10.1038/ s41598-020-74092-y
Ng YJ, Tham PE, Khoo KS, Cheng CK, Chew KW, Show PL (2021) A comprehensive review on the techniques for coconut oil extraction and its application. Bioprocess Biosyst Eng 44:1807-1818. https://doi.org/10.1007/s00449-021-02577-9

Nguyen TT, Mikkelsen MD, Tran V, Trang V, Rhein-Knudsen N, Holck J, Rasin AB, Cao H, Van T, Meyer AS (2020) Enzymeassisted fucoidan extraction from brown macroalgae Fucus distichus subsp. evanescens and Saccharina latissima. Mar Drugs 18(6):296. https://doi.org/10.3390/md18060296

Nogueira GF, de Oliveira RA, Velasco JI, Fakhouri FM (2020) Methods of incorporating plant-derived bioactive compounds into films made with agro-based polymers for application as food packaging: a brief review. Polymers 12(11):2518. https://doi.org/ $10.3390 /$ polym 12112518

Pal C, Jadeja GC (2020) Microwave-assisted extraction for recovery of polyphenolic antioxidants from ripe mango (Mangifera indica L.) peel using lactic acid/sodium acetate deep eutectic mixtures. Food Sci Technol Int 26(1):78-92. https://doi.org/10.1177/10820 13219870010

Patel VR, Dumancas GG, Viswanath LCK, Maples R, Subong BJJ (2016) Castor oil: properties, uses, and optimization of processing parameters in commercial production. Lipid Insights 9(1):112. https://doi.org/10.4137/LPI.S40233

Pereira T et al. (2020) Optimization of phycobiliprotein pigments extraction from red algae Gracilaria gracilis for substitution of synthetic food colorants. Food Chem 321. https://doi.org/10. 1016/j.foodchem.2020.126688

Perera P, Ekanayake S, Ranaweera K (2017) Antidiabetic compounds in Syzygium cumini decoction and ready to serve herbal drink. eCAM 1083589. https://doi.org/10.1155/2017/1083589

Pingret D, Fabiano-Tixier AS, Chemat F (2013) Ultrasound assisted extraction. In: Natural product extraction: principles and applications, Royal Society of Chemistry, pp 89-112.

Pinzon I, Razal RA, Mendoza RC, Carpio RB, Eusebio R (2020) Parametric study on microwave-assisted extraction of runo (Miscanthus sinensis Andersson) dye and its application to paper and cotton fabric. Biotechnol Rep 28:e00556. https://doi.org/ 10.1016/j.btre.2020.e00556

Pogorzelska-Nowicka E, Atanasov AG, Horbańczuk J, Wierzbicka A (2018) Bioactive compounds in functional meat products. Molecules 23(2):307. https://doi.org/10.3390/molecules23020307

Poojary MM, Orlien V, Passamonti P, Olsen K (2017) Enzyme-assisted extraction enhancing the umami taste amino acids recovery from several cultivated mushrooms. Food Chem 234:236-244. https:// doi.org/10.1016/j.foodchem.2017.04.157

Priyadarshi S, Balaraman M, Naidu MM (2020) Ionic liquid-based microwave-assisted extraction of Heneicos-1-ene from coriander foliage and optimizing yield parameters by response surface methodology. Prep Biochem Biotechnol 50(3):246-251. https:// doi.org/10.1080/10826068.2019.1687519

Puri M, Sharma D, Barrow CJ (2012) Enzyme-assisted extraction of bioactives from plants. Trends Biotechnol 30(1):37-44. https:// doi.org/10.1016/j.tibtech.2011.06.014

Quagliariello V, Iaffaioli RV, Falcone M, Ferrari G, Pataro G, Donsì F (2016) Effect of pulsed electric fields - assisted extraction on anti-inflammatory and cytotoxic activity of brown rice bioactive compounds. Int Food Res J 87:115-124. https://doi.org/10. 1016/j.foodres.2016.07.005

Ramkissoon A, Seepersaud M, Maxwell A, Jayaraman J, Ramsubhag A (2020) Isolation and antibacterial activity of indole alkaloids from Pseudomonas aeruginosa UWI-1. Molecules 25(16):3744. https://doi.org/10.3390/molecules25163744

Raynie DE (2019) Looking at the past to understand the future: Soxhlet extraction. LC GC N Am 37(8):510-513. Retrieved from https:// www.chromatographyonline.com/view/looking-past-understandfuture-soxhlet-extraction 
Rehman MU, Abdullah, Khan F, Niaz K (2020) Introduction to natural products analysis. In: Recent Advances in Natural Products Analysis. Elsevier Inc. pp 3-15. https://doi.org/10.1016/b978-012-816455-6.00001-9

Reynoso-Camacho R, Sotelo-González AM, Patiño-Ortiz P, RochaGuzmán NE, Pérez-Ramírez IF (2021) Berry by-products obtained from a decoction process are a rich source of low- and high-molecular weight extractable and non-extractable polyphenols. Food Bioproduct Process 127:371-387. https://doi.org/10. 1016/j.fbp.2021.03.014

Ricarte GN, Coelho M, Marrucho IM, Ribeiro BD (2020) Enzymeassisted extraction of carotenoids and phenolic compounds from sunflower wastes using green solvents. 3 Biotech 10(9):405. https://doi.org/10.1007/s13205-020-02393-0

Ridgway K (2012) Sample preparation for food contaminant analysis. LC GC Eur 25(2):1-8

Ritala A, Häkkinen ST, Toivari M, Wiebe MG (2017) Single cell protein-state-of-the-art, industrial landscape and patents 20012016. Front Microbiol 8:2009. https://doi.org/10.3389/fmicb. 2017.02009

Rodrigues AM, Vieira Falé PL, Madeira P, Pacheco, R, Florêncio M H, Ascensão L, Marques Serralheiro ML (2020) Phenolic profile and biological activities of decoctions from Santolina impressa, a Portuguese endemic species. J Herb Med 21. https://doi.org/10.1016/j.hermed.2020.100335

Rodriguez-Jasso RM, Mussatto SI, Pastran L, Aguilar CN, Teixeira JA (2011) Microwave-assisted extraction of sulfated polysaccharides (fucoidan) from brown seaweed. Carbohydr Polym 86(3):1137-1144. https://doi.org/10.1016/j.carbpol.2011.06. 006

Rodríguez-Pérez C, Gilbert-López B, Mendiola JA, QuirantesPiné R, Segura-Carretero A, Ibáñez E (2016) Optimization of microwave-assisted extraction and pressurized liquid extraction of phenolic compounds from Moringa oleifera leaves by multiresponse surface methodology. Electrophoresis 37(13):19381946. https://doi.org/10.1002/elps.201600071

Roohinejad S, Nikmaram N, Brahim M, Koubaa M, Khelfa A, Greiner $R$ (2017) Potential of novel technologies for aqueous extraction of plant bioactives. In: Water extraction of bioactive compounds: From plants to drug development, Elsevier, pp 399-419. https:// doi.org/10.1016/B978-0-12-809380-1.00016-4

Saadouli I, el Euch IZ, Trabelsi E, Mosbah A, Redissi A, Ferjani R, Fhoula I, Cherif A, Sabatier JM, Sewald N, Ouzari HI (2020) Isolation, characterization and chemical synthesis of large spectrum antimicrobial cyclic dipeptide (L-leu-l-pro) from Streptomyces misionensis v16r3y1 bacteria extracts. a novel $1 \mathrm{H}$ NMR metabolomic approach. Antibiotics 9(5):270. https://doi.org/10. 3390/antibiotics 9050270

Sadh PK, Kumar S, Chawla P, Duhan JS (2018) Fermentation: a boon for production of bioactive compounds by processing of food industries wastes (By-Products). Molecules 23(10):2560. https:// doi.org/10.3390/molecules23102560

Saldarriaga-Hernandez S, Hernandez-Vargas G, Iqbal HMN, Barceló D, Parra-Saldívar R (2020) Bioremediation potential of Sargassum sp. biomass to tackle pollution in coastal ecosystems: Circular economy approach. Sci Total Environ 715. https://doi.org/ 10.1016/j.scitotenv.2020.136978

Salgado-Roman M, Botello-Álvarez E, Rico-Martínez R, JiménezIslas H, Cárdenas-Manríquez M, Navarrete-Bolaños JL (2008) Enzymatic treatment to improve extraction of capsaicinoids and carotenoids from chili (Capsicum anпииm) fruits. J Agric Food Chem 56(21):10012-10018. https://doi.org/10.1021/ jf $801823 \mathrm{~m}$

Santiago M (2013) Thin layer chromatography. Methods in Enzymology: Cell, Lipid and Carbohydrate 533:303-324. https://doi.org/ 10.1016/B978-0-12-420067-8.00024-6
Santos PH, Kammers JC, Silva AP, Oliveira JV, Hense H (2021) Antioxidant and antibacterial compounds from feijoa leaf extracts obtained by pressurized liquid extraction and supercritical fluid extraction. Food Chem 344. https://doi.org/10.1016/j.foodchem. 2020.128620

Saptarini NM, Wardati Y (2020) Effect of extraction methods on antioxidant activity of papery skin extracts and fractions of Maja Cipanas onion (Allium cepa L.var. ascalonicum). ScientificWorldJournal, 3280534. https://doi.org/10.1155/2020/32805 34

Shahi KS, Didar Z, Hesarinejad MA, Vazifedoost M (2021) Optimized pulsed electric field-assisted extraction of biosurfactants from Chubak (Acanthophyllum squarrosum) root and application in ice cream. J Sci Food Agric 101(9):3693-3706. https://doi.org/ 10.1002/jsfa. 11000

Sharmeen JB, Mahomoodally FM, Zengin G, Maggi F (2021) Essential oils as natural sources of fragrance compounds for cosmetics and cosmeceuticals. Molecules 26(3):666. https://doi.org/10.3390/ molecules 26030666

Shiekh AK, Olatunde OO, Zhang B, Huda N, Benjakul S (2021). Pulsed electric field assisted process for extraction of bioactive compounds from custard apple (Annona squamosa) leaves. Food Chem 359. https://doi.org/10.1016/j.foodchem.2021. 129976

Shimotori Y, Watanabe T, Kohari Y, Chiou TY, Ohtsu N, Nagata Y, Murata M (2020) Enzyme-assisted extraction of bioactive phytochemicals from Japanese peppermint (Mentha arvensis L. cv. 'Hokuto'). J oleo sci 69(6):635-642. https://doi.org/10.5650/jos. ess 19181

Shirahigue L, Antonini S (2020) Agro-industrial wastes as sources of bioactive compounds for food and fermentation industries. Ciênc Rural 50(4). https://doi.org/10.1590/0103-8478cr2019 0857

Shrinet K, Singh RK, Chaurasia AK, Tripathi A, Kumar A (2021) Bioactive compounds and their future therapeutic applications. In: Natural bioactive compounds, technological advancements. Elsevier Inc. pp 337-362. https://doi.org/10.1016/b978-0-12820655-3.00017-3

Sichert A, le Gall S, Klau LJ, Laillet B, Rogniaux H, Aachmann FL, Hehemann JH (2021) Ion-exchange purification and structural characterization of five sulfated fucoidans from brown algae. Glycobiology 31(4):352-357. https://doi.org/10.1093/glycob/ cwaa064

Silva AM, Pinto D, Fernandes I, Gonçalves Albuquerque T, Costa HS, Freitas V, Rodrigues F, Oliveira MBPP (2019) Infusions and decoctions of dehydrated fruits of Actinidia arguta and Actinidia deliciosa: bioactivity, radical scavenging activity and effects on cells viability. Food Chem 289:625-634. https://doi.org/10. 1016/j.foodchem.2019.03.105

Silva VDM, Macedo MCC, dos Santos AN, Silva MR, Augusti R, Lacerda ICA, Melo JOF, Fante CA (2020) Bioactive activities and chemical profile characterization using paper spray mass spectrometry of extracts of Eriobotrya japonica Lindl. leaves. RCM 34(19). https://doi.org/10.1002/rcm.8883

Sinha RP, Häder DP (2021) Introduction. In: Natural bioactive compounds: Technological advancements. Elsevier Inc. pp 1-17. https://doi.org/10.1016/C2019-0-00797-2

Solaberrieta I, Jiménez A, Cacciotti I, Garrigós MC (2020) Encapsulation of bioactive compounds from Aloe vera agrowastes in electrospun poly (ethylene oxide) nanofibers. Polymers 12(6):1323. https://doi.org/10.3390/polym12061323

Spiridon I, Anghel N, Dinu MV, Vlad S, Bele A, Ciubotaru BI, Verestiuc L, Pamfil D (2020) Development and performance of bioactive compounds-loaded cellulose/collagen/ polyurethane materials. Polymers 12(5):1191. https://doi.org/10.3390/POLYM 12051191 
Sumampouw GA, Jacobsen C, Getachew AT (2021) Optimization of phenolic antioxidants extraction from Fucus vesiculosus by pressurized liquid extraction. J Appl Phycol 33(2):1195-1207. https://doi.org/10.1007/s10811-020-02362-3

Süntar I (2020) Importance of ethnopharmacological studies in drug discovery: role of medicinal plants. Phytochem Rev 19(5):11991209. https://doi.org/10.1007/s11101-019-09629-9

Sut S, Dall'Acqua S, Zengin G, Senkardes I, Bulut G, Cvetanović A, Stupar A, Mandić A, Picot-Allain C, Dogan A, Ibrahime Sinan $\mathrm{K}$, Mahomoodally F (2019) Influence of different extraction techniques on the chemical profile and biological properties of Anthemis cotula L.: Multifunctional aspects for potential pharmaceutical applications. J Pharm Biomed Anal 173:75-85. https:// doi.org/10.1016/j.jpba.2019.05.028

Swain PK (2017) Utilisation of agriculture waste products for production of biofuels: a novel study. Mater Today: Proc 4(11):1195911967. https://doi.org/10.1016/j.matpr.2017.09.117

Talekar S, Patti AF, Singh R, Vijayraghavan R, Arora A (2018) From waste to wealth: High recovery of nutraceuticals from pomegranate seed waste using a green extraction process. Ind Crop Prod 112:790-802. https://doi.org/10.1016/j.indcrop.2017.12.023

Uwineza PA, Waśkiewicz A (2020) Recent advances in supercritical fluid extraction of natural bioactive compounds from natural plant materials. Molecules 25(17):3847. https://doi.org/10.3390/ molecules 25173847

Vazquez-Roig P, Picó Y (2015) Pressurized liquid extraction of organic contaminants in environmental and food samples. Trends Analyt Chem 71:55-64. https://doi.org/10.1016/j.trac. 2015.04.014

Vieira SF, Ferreira H, Neves NM (2020) Antioxidant and anti-inflammatory activities of Cytocompatible Salvia officinalis extracts: a comparison between traditional and soxhlet extraction. Antioxidants 9(11):1157. https://doi.org/10.3390/antiox9111157

Vijay N, Shashikant D, Mohini P (2019) Assessment of antidiabetic potential of Musa acuminata peel extract and its fractions in experimental animals and characterisation of its bioactive compounds by HPTLC. Arch Physiol Biochem. https://doi.org/10. 1080/13813455.2019.1683585

Villanueva-Bermejo D, Calvo MV, Castro-Gómez P, Fornari T, Fontecha J (2019) Production of omega 3-rich oils from underutilized chia seeds. Comparison between supercritical fluid and pressurized liquid extraction methods. Food Res Int 115:400-407. https://doi.org/10.1016/j.foodres.2018.10.085

Vogt S, Löffler K, Dinkelacker AG, Bader B, Autenrieth IB, Peter S, Liese J (2019) Fourier-transform infrared (FTIR) spectroscopy for typing of clinical Enterobacter cloacae complex isolates. Front Microbiol 10:2582. https://doi.org/10.3389/fmicb.2019. 02582

Wang Y, Guo QL, Li RF, Xu CB, Zhu CG, Shi JG (2019) Two folatederived analogues from an aqueous decoction of Uncaria rhynchophylla. Chin J Nat Med 17(12):928-934. https://doi.org/10. 1016/S1875-5364(19)30115-3

Weggler BA, Gruber B, Teehan P, Jaramillo R, Dorman FL (2020) Inlets and sampling. In: Separation science and technology. Elsevier Inc. New York. Vol 12, pp 141-203. https://doi.org/10.1016/ B978-0-12-813745-1.00005-2
Wianowska D, Wiśniewski M (2015) Simplified procedure of silymarin extraction from Silybum marianum L. Gaertner. J Chromatogr Sci 53(2): 366-372. https://doi.org/10.1093/chromsci/bmu049

Wong P Lou Ramli NS, Tan CP, Azlan A, Abas F (2021) Metabolomic analysis reveals the valuable bioactive compounds of Ardisia elliptica. Phytochem Anal 32(5):685-697. https://doi.org/10. 1002/pca.3015

Xie Y, Kang R, Tang D (2019) The flavone Baicalein and its use in gastrointestinal disease. In: Dietary interventions in liver disease, 1st edn. Elsevier, pp. 145-155. https://doi.org/10.1016/B978-012-814466-4.00012-4

Yu J, Zhang J, Sun X, Xiao C, Wang X, Zhou T (2020) Comprehensive separation of iridoid glycosides and triterpenoid saponins from Dipsacus asper with salt-containing solvent by high-speed countercurrent chromatography coupled with recycling mode. J Sep Sci 43(7):1265-1274. https://doi.org/10.1002/jssc.201901186

Zakaria SM, Mustapa Kamal SM, Harun MR, Omar R, Siajam SI (2020) Extraction of phenolic compounds from Chlorella sp. microalgae using pressurized hot water: kinetics study. Biomass Convers Biorefin https://doi.org/10.1007/s13399-020-01027-y

Zerrifi SEA, el Khalloufi F, Oudra B, Vasconcelos V (2018) Seaweed bioactive compounds against pathogens and microalgae: potential uses on pharmacology and harmful algae bloom control. Mar Drugs 16(2):55. https://doi.org/10.3390/md16020055

Zerrifi SEA, Mugani R, Redouane EM, el Khalloufi F, Campos A, Vasconcelos V, Oudra B (2021) Harmful Cyanobacterial Blooms (HCBs): innovative green bioremediation process based on anti-cyanobacteria bioactive natural products. Arch Microbiol 203(1):31-44. https://doi.org/10.1007/s00203-020-02015-6

Zghaibi N, Omar R, Kamal S, Biak D, Harun R (2019) Microwaveassisted brine extraction for enhancement of the quantity and quality of lipid production from microalgae Nannochloropsis sp. Molecules 24(19):3581. https://doi.org/10.3390/molecules2 4193581

Zhang J, Wu C, Gao L, Du G, Qin X (2020a) Astragaloside IV derived from Astragalus membranaceus: a research review on the pharmacological effects. Adv Pharmacol 87:89-112. https://doi.org/ 10.1016/bs.apha.2019.08.002

Zhang Z, Wu X, Lai Y, Li X, Zhang D, Chen Y (2020b) Efficient extraction of bioenergy from Cinnamomum camphora leaves. Front Energy Res 8:90. https://doi.org/10.3389/fenrg.2020.00090

Zhang QW, Lin LG, Ye WC (2018) Techniques for extraction and isolation of natural products: a comprehensive review. Chinese Med 13:20. https://doi.org/10.1186/s13020-018-0177-x

Zhao X, Zhang X, Liu H, Zhu H, Zhu Y (2019) Enzyme-assisted extraction of astaxanthin from Haematococcus pluvialis and its stability and antioxidant activity. Food Sci Biotechnol 28(6):1637-1647. https://doi.org/10.1007/s10068-019-00608-6

Zlabur JŠ, Voća S, Dobričević N, Brncic M, Dujmic F, Brnčić SR (2015) Optimization of ultrasound assisted extraction of functional ingredients from Stevia rebaudiana Bertoni leaves. Int Agrophys 29(2):231-237. https://doi.org/10.1515/ intag-2015-0017

Publisher's note Springer Nature remains neutral with regard to jurisdictional claims in published maps and institutional affiliations. 